\title{
Under the influence of traumatic events, new ideas, economic experts and the ICT revolution - the economic policy and macroeconomic performance of Sweden in the
} 1990s and 2000s*

\author{
Lennart Erixon* \\ Department of Economics, Stockholm University \\ (August 21, 2011)
}

\begin{abstract}
:
The new economic-policy regime in Sweden in the 1990s included deregulation, central-bank independence, inflation targets and fiscal rules but also active labour market policy and voluntary incomes policy. This article describes the content, determinants and performance of the new economic policy in Sweden in a comparative, mainly Nordic, perspective. The new economicpolicy regime is explained by the deep recession and budget crisis in the early 1990s, new economic ideas, EU integration and the power of economic experts. In the 1998-2007 period, Sweden displayed relatively low inflation and high productivity growth, but unemployment was high, especially by national standards. The restrictive monetary policy was responsible for the low inflation and the dynamic ICT sector was decisive for the productivity miracle. Furthermore, productivity increases in the ICT sector largely explains why the Central Bank undershot its inflation target in the late 1990s and early 2000s. The new economic-policy regime in Sweden performed well during the global financial crisis. However, as in other OECD countries the moderate increase in unemployment was largely attributed to labour hoarding. And the rapid recovery of the Baltic countries made it possible for Sweden to avoid a bank crisis.
\end{abstract}

Keywords: Swedish model, Swedish economic policy, Swedish Central Bank, economic experts, Sweden's macroeconomic performance, financial crisis, new economic-policy regime

\footnotetext{
JEL classification: D78, E24, E31, E58 E62, E63 E64, J51, N14, O47, O50

* The paper will be published in Comparative Social Research, Vol. 28, 2011 together with articles on Denmark, Norway, Finland and Iceland by Jørgen Goul Andersen, Lars Mjøset, Ådne Cappelen, Juhana Vartiainen and Stefán Ólafsson. The participants in the Nordic Economic Policy Project, especially Lars Mjøset and Juhana Vartiainen, have made very valuable comments on earlier draft.
}

* Contact author: Lennart Erixon, Department of Economics, Stockholm University. Tel.: +46 8 162136; fax.: +46 8 159482; e-mail: lex@ne.su.se. 


\section{INTRODUCTION}

Despite strong negative demand and supply shocks, Sweden succeeded in the 1970s and 1980s to maintain low rates of unemployment. In these decades, however, Sweden displayed low GDP per capita growth in comparison with other OECD countries and also relatively high inflation, especially during the second half of the 1980s. In the early 1990s the country experienced an economic crisis without correspondence in other OECD countries with the exception for her neighbor Finland. During the crisis politicians, economic experts and social researchers abroad announced the death of "the Swedish model". The obituary of the model was written by people with disparate theoretical orientations and social values.

Sweden's macroeconomic development since the mid-1990s, including her fast recovery from the Great Recession, made foreign observers inclined (once again) to consider the country as an example worth following. Today, Sweden occupies, like the other Nordic countries, a top position when countries are ranked in terms of macroeconomic stability, international competitiveness and sustainable growth. Some observers highlight the advantages of the "old" Swedish or Nordic model combining openness with generous welfare programs, active labour market policy (to increase labour mobility) and income equalization (Pontusson 2006, Gylfason et al. 2010). Other observers refer to the beneficial effects of a new Swedish model with larger income differentials, deregulation, 
e.g. the promulgation of private provisions of welfare services, reductions in taxes, lower compensation rates in the social insurance systems, and strict rules for fiscal and monetary policies (Erlandsen and Lundsgaard 2007, Hüfner 2007, Lindbeck, 2007, Fregert and Jonung 2008). The Nordic countries are still among the OECD countries with the smallest income gaps (both before and after taxes), the largest public sector (although Norway has low public expenditure in relation to GDP), the highest labour-force participation rates and the strongest position for organized labour (OECD 2010, Table I and Table B, OECD 2011 Table 25 and 26, Statistics Sweden 2006, 11, Visser 2006, Table 3). However, with respect to income distribution, labour legislation, public employment, income taxes and economic policy, the Nordic countries converged to the OECD and EU averages in the 1990s and 2000s.

This chapter focuses on the introduction of a new economic-policy regime in Sweden in the 1990s and 2000s. Deregulation of financial, product and labour markets and rulebased macroeconomic policy are paramount features of the new regime. The Swedish adjustment in the 1990s and 2000s to international theories, ideologies and agreements shall not conceal, however, that the macroeconomic development in the country was also affected by the priorities and institutions of earlier economic-policy regimes, primarily "voluntary" incomes policy and active labor market policy (ALMP). The notion of a new regime will be used to describe Swedish economic policy in the 1990s and 2000s despite the fact that there were relics of older strategies in the new strategy. There were also some turbulent years before all parts of the new regime was in place. A distinction will be 
made between the phases where the new strategy was developed (1992-1997), fully applied as a routine (1998-2007) and seriously tested (2008-2011).

The chapter has also the ambition to disentangle strategic factors behind the deregulation and change to a new macroeconomic policy in Sweden. It emphasizes the negative experiences of economic policy in the past and of disappointing events, primarily the deep, basically Swedish (or Nordic), recession at the beginning of the 1990s. In the analysis of the reorientation of economic policy and structural reforms in Sweden the focus is also on the import of new economic theories, the professionalism of economic policy, EU integration and the declining influence of LO, the central blue-collar confederation. These phenomena will be considered as prime driving forces, thus each determinant have an independent status, at least partially, to other political-institutional and economic-structural conditions and the macroeconomic development in Sweden in the 1990s and 2000s. For example, new macroeconomics was obviously an exogenous determinant of Swedish economic policy. Earlier economic-policy doctrines had largely been based on ideas developed by the Stockholm School of Economics in the 1930s and 1940s and by trade-union economists in the early postwar period, see the Rehn-Meidner model. The fact that the new macroeconomic theories were developed by AngloAmerican economists makes it reasonable to consider them as independent of the actual economic development in Sweden.

A further aim of the chapter is to assess the importance of the new economic-policy regime for the apparent macroeconomic success of Sweden in the 1998-2007 period. The 
chapter stresses the lack of serious demand and supply shocks at the international level. Furthermore, high Swedish growth reflected some favorable economic-structural conditions that are not necessarily related to the new economic-policy regime. The chapter sheds light on the role of the ICT sector for the "productivity wonder" and also for the low inflation in Sweden in an international perspective. Restrictive monetary policies e.g. reflected that the Swedish Central Bank underestimated the ICT sector's productivity growth. Monetary restraint largely explains why the Swedish success under a new economic-policy regime was less obvious in terms of unemployment.

The chapter finally evaluates the performance of the new economic policy regime in Sweden in the 2008-2011 period. Monetary policy was facilitated by the change from stagflation to recession in this period and fiscal policy by the initial public budget surplus; this surplus was not primarily the result of the fiscal rules implemented during the second half of the 1990s but of the public budget crisis in the early 1990s. By a combination of earlier fiscal consolidation, government bailouts in the financial sector, countercyclical monetary policy, flexible exchange-rates and luck Sweden could avoid an economic crisis in the late 2000s similar to that in the early 1990s. But Swedish unemployment was high at the end of the 2000s, especially by national standards. In fact, in the late 1990s and the 2000s, Sweden neither succeeded in returning to the low unemployment rates of the 1980s (and the earlier postwar decades), nor belonged to a group of OECD countries with the lowest rate of open unemployment. 


\title{
THE DEVELOPMENT OF A NEW ECONOMIC POLICY REGIME
}

\author{
A brief description of the old regime
}

Economic policy in Sweden during the 1980s was shaped by the profit crisis, the losses of Swedish market shares and the emergence of a structural public budget deficit during the second half of the 1970s. After OPEC II, centre-right and social democratic governments abandoned their Keynesian policy after OPEC I of maintaining low rates of unemployment by stimulating domestic demand. (The Swedish governments in the postwar period are surveyed in Appendix 1.) Swedish fiscal policy was predominantly tight in the 1980s in order to reduce the deficits in the public budget and the current account and also to speed up the transfer of resources to the exposed sector. To boost profits in the exposed sector and increase Swedish market shares the social democrats devalued the SEK (the krona) in 1982. Together with the devaluation by a non-socialist government the year before the SEK was reduced by 26 per cent in relation to the currencies of competing countries. Monetary policy was tied by the Swedish unilateral system of fixed exchange rates on an increasingly global financial market. During the

first half of the 1980s, both non-socialist and social democratic governments introduced extensive ALMP programs to fight unemployment in line with the Rehn-Meidner model.

By giving priority to full employment the social democrats eventually abandoned their plans to link the SEK to the German Mark after the 1982 devaluation. Instead, the government tried to fight inflation during the Reagan boom and in the aftermath of the 
devaluations by pleading the central trade unions for wage moderation and by declaring that new devaluations were excluded. Sweden gradually switched to a hard-currency policy although the policy was not institutionalized until the early 1990s. In the late 1980s, the main argument for fiscal restraint by the social democratic government was to cool down overheating. But there was a growing skepticism among leading social democrats and their experts towards discretionary economic policy. The gradual change to hard-currency policy, but also the deregulations of domestic and foreign capital markets by the social democrats during the second half of the 1980s (see next section), were the first indications of a new economic-policy regime in Sweden.

\section{The components of the new regime}

The two devaluations (1981-1982), the long international boom, the dismantling of restrictions on bank lending (1985) in combination with a tax system favouring borrowing led to severe overheating in Sweden. During the second half of the 1980s share prices and prices in real-estate markets skyrocketed. A substantial part of investment in stocks and commercial building were directly financed by new financial instruments and institutions (Ingves and Lind 1998). A bubble in markets for stocks and commercial buildings in particular reinforced the tendency to overheating in the Swedish economy. The subsequent collapse of Swedish stock and housing markets (including commercial buildings) was unleashed by an increase in (West-)German long-run interest rates (1989-1990), the bankruptcy of some new financing companies (initially Nyckeln), leading to credit losses and lending restrictions by the commercial banks (Autumn 1990), 
and by an international recession (1990-1991). In 1992, liquidations and financial problems for surviving companies elicited, as in Norway and (especially) in Finland, a bank crisis in Sweden. A tax reform 1990-1991 contributed to the fall in Swedish stock and housing prices by making it less favorable to borrow.

Negative wealth effects of falling prices on stocks and houses and lesser household confidence (e.g. through higher unemployment) initiated a dramatic reduction in private consumption 1991-1994. ${ }^{1}$ Private consumption was further hampered by the increase in international (German) interest rates in 1992 having a negative effect on households' liquidity and a positive effect on their incentives to repay loans. Furthermore, the simultaneous decline in domestic and foreign demand caused a reduction in Swedish investments 1991-1993 by 38 per cent in the business sector and by 35 per cent in the total economy, a much larger decrease than in all other OECD countries except Finland (OECD 2003, Table 5). The lower rate of inflation in 1992 contributed (together with sluggish nominal interest rates) to the fall in Swedish investments by leading to higher real interest rates.

The change to flexible exchange rates in November 1992 was one pillar of the new economic-policy regime in Sweden. A regime shift in Swedish economic policy had already occurred through the gradual change to hard-currency policy in the 1980s. This policy became more explicit after the elimination of the currency controls in the late 1980s. In October 1990, a social democratic government had faced a speculative attack

\footnotetext{
${ }^{1}$ The tax reform 1990-1991 had negative effects on household liquidity and created incentives for repayment of loans. But these negative effects on aggregate demand were neutralized by the fact that the reform was underfinanced.
} 
against the SEK. The government responded by announcing a restrictive fiscal program and a Swedish membership in the EU; Sweden formally applied for membership in the summer of 1991. In May 1991, the social democrats tried to restore the lost confidence in the SEK by linking it to the ECU. In 1992, the higher interest rates in Germany (related to the unification) and global recession tendencies led to unrest on European financial markets. The currency crisis in September 1992, when Sweden was ruled by a centreright coalition government, induced new speculations against the SEK. During two days the Central Bank's prime interest rate soared to the record level of 500 per cent. When the SEK was under a new attack in November 1992 the Central Bank decided (in fact before having consulted the centre-right government) to let the SEK float.

With flexible exchange rates and free capital movements across borders monetary policy attains a central role in the stabilization of output and employment (see the MundellFleming model). But the switch to flexible exchange rates in Sweden was followed by a decision by the Central Bank in January 1993 to adopt an inflation target of 2 per cent allowing a deviation of 1 percentage points in both directions. The target was used a guideline for Swedish monetary policy from 1995. Furthermore the Central Bank had gradually become more independent in the 1980s and 1990s. Its independence and superior goal of price stability were finally legally settled in January $1999 .^{2}$ In February 1999, the new Executive Board of the Central Bank added that monetary policy should also consider the stability of the real economy although without jeopardizing the inflation target. Negative supply shocks shed light on a real conflict between the goals of low

\footnotetext{
${ }^{2}$ There is an immense literature on the ranking of central-bank independence. Most of the rankings are based on data before the central bank reforms in the 1990s. It seems, however, that Sweden in the late 1990s belonged to a group of OECD countries with medium independence (Masłowska 2007, 33).
} 
inflation and output stability in economic policy. Today, the Swedish Central Bank advocates the use of flexible inflation targets by minimizing a (quadratic) loss function namely the deviation of (expected) inflation from the target and (expected) GDP from the potential level. Monetary policy might give priority to the stabilization of GDP and employment, thus the target of 2 per cent inflation must not be satisfied in the short run (Svensson 2010, 60-62, Ingves 2011).

Swedish monetary policy was cautiously expansive in 1993 and then restrictive 19941995. Inflation had decreased radically in 1992, but increased again during the following year. The Central Bank wished to tame inflation expectations in general and, specifically, to counteract the inflationary tendencies through the weakening of the SEK (and the expansionary fiscal policy). In the first year with flexible exchange rates (1993), the SEK was depreciated by 25 per cent against the currencies of competing nations, a weakening of the SEK similar to that after the devaluations in the early 1980s. The Central Bank saw the growing gap between Swedish and German interests in 1994-1995 (after a decline in 1993) as an indication that global financial markets had still weak confidence in the ability and willingness of economic policy-makers in Sweden to reduce inflation.

In the 1990s, there was also a change in the guidelines for and orientation of Swedish fiscal policy. It was primarily a centre-right government (1991-1994) that had to face the deep Swedish recession. The previous social democratic government had been occupied with the task of combating overheating and its consequences and was thus unprepared to meet the dramatic downturn in the economy until it fell in September 1991. During the 
currency crisis in September1992 the centre-right government tried, in collaboration with the social democrats, to please financial actors by a crisis package aimed at improving Swedish competitiveness (mainly reductions in payroll taxes). This response to the crisis followed the economic-policy routine of the 1980s focusing on Swedish market shares. The SEK was definitely overvalued at the beginning of the 1990s. But undoubtedly politicians and their experts overreacted on the loss of Swedish market shares (volume) in the late 1980s and early 1990s ignoring that the worsening of the current account (and the higher nominal wages) at that time reflected domestic overheating. Furthermore, the export decline during the international recession 1990-1991 was a catalyst, not a major explanation, for the Swedish crisis. ${ }^{3}$

A second crisis package by the centre-right government together with the social democratic opposition in late September 1992 contained extraordinary measures to improve the public budget balance (primarily increases in consumer taxes and reductions in public transfers). In 1992, worse business-cycle conditions (see built-in stabilizers) and bank subsidies to avoid a collapse of the Swedish financial market had resulted in a large budget deficit for the consolidated public sector. Swedish politicians felt impelled to improve the public budget balance by deflationary fiscal measures. They suspected (probably correctly) in late September 1992 that the growing budget deficit had contributed to the weak confidence in the SEK among financial actors.

\footnotetext{
${ }^{3}$ But by her specialization in business-cycle sensitive products (raw materials and investment goods) and automobiles, Sweden was particularly hard hit by the international recession in 1990-1991.
} 
Notwithstanding the fiscal austerity measures in Autumn 1992 the public budget deficit in Sweden approached a percentage share of GDP in 1993 that could only be compared with that in Greece at that time. The centre-right coalition government was too divided to implement a restrictive fiscal policy until the final year in power (1994). According to OECD estimates, in 1992-1993, expansionary fiscal policy was almost equally responsible as built-in stabilizers for the Swedish public budget deficit (OECD 2003, Table 28 and 29). For example, the bank support in 1991-1993 amounted to 65 billion SEK. The social democratic government succeeding the centre-right coalition became the main actor in the endeavours to reduce the Swedish public budget deficit and public debt. The tight fiscal policy 1994-1998 implemented primarily by a social democratic government was the main reason why the deficit for the consolidated public sector disappeared in 1998. In fact, the fiscal austerity measures in Sweden in the mid-1990s had no correspondences in other OECD countries from the early 1970s (from which time statistics are available) until the 2008-2011 period (Erixon 2010, 696-697) and it was combined with a restrictive monetary policy 1994-1995 (see above). The restrictive economic policy when the rate of unemployment was still high, especially by national standards, was a significant departure from Swedish economic policy since the early 1930s.

In the 1990s, there were also some new institutional conditions for fiscal policy in Sweden. The progressive taxes had been reduced and the tax based broadened through the tax reform 1990-1991. A budget reform in the mid-1990s accepted by both the centreright coalition and the following social democratic government restricted the possibility 
for the Parliament to increase public expenditure by a breakdown of the budget items (see also the section on the strategic role of professional economists, below). Furthermore, when regaining power in 1994, the social democrats introduced rules for fiscal discipline. In 1995, they decided to put a ceiling on expenditure by central government; the rule was applied from 1997. The same year the social democratic government also introduced a fiscal target for the consolidated public sector requiring a surplus of 2 per cent of GDP over the business cycle. The reduction of the target from 2 to 1 per cent in 2006 was not a softening of the target. Rather, it was the result of EU regulations requiring that certain parts of the pension system should be included in the private sector. Finally, in 1997, the social democratic government decided to restrict the extent to which local and county governments could pass budgets with a deficit. The new law, introduced in 2000, stated that local and county governments must eliminate budget deficits within two years.

The introduction of explicit domestic fiscal rules was not general in the OECD countries. Some of the EU countries that later became members of the EMU are not governed today by any domestic fiscal rules (Ireland, Italy, France and Greece). Furthermore, the Swedish rules were more explicit, radical or adopted earlier than the corresponding rules in other European OECD countries (see CESifo 2009). For example, Norway had no fiscal guidelines until 2001, and the country has still no expenditure target. Besides, the construction of the Norwegian rule makes fiscal policy expansionary when oil prices are increasing (Jafarov and Leigh 2007). Danish governments make up medium-terms plans for the public budget balance but are not ruled by any fixed budget or public expenditure targets. Finland has had a spending limit system for central government since 1991, but 
no domestic rules for the public budget balance thus the country is here a follower of the EU Stability and Growth Pact.

Deregulation was another component of the new economic-policy regime in Sweden in the 1990s and 2000s. The deregulation of domestic capital markets in the mid-1980s was soon followed by the dismantling of currency controls. From 1987 there was no longer any obligation for Swedish companies to finance foreign direct investments by foreign capital. The deregulation of Swedish currency markets were completed in 1989 as all restrictions on Swedish citizens' purchases of real estates, stocks and bonds abroad were terminated. The character and timing of financial-market deregulation in Sweden was similar to that in Norway and Finland.

Through a social democratic proposition in the early 1990s the agricultural sector became more deregulated in Sweden than in most other European countries. This sector was regulated again when Sweden joined the EU in 1995. But Sweden had entered the road to deregulation of markets for products and services by privatization and the elimination of legal barriers to price competition and market entry. In 1991, the social democratic government decided to allow private employment services including companies hiring out workers (bemanningsföretag). In 1993, the subsequent centre-right government extended the possibilities of private employment services. In the 1991-1994 period, the centre-right government also deregulated the markets for telecommunication, transport and electricity. A similar regulation wave did also take place in other OECD countries (including other Nordic countries). But it seems that the deregulation of these markets 
was earlier and more far-reaching in Sweden than in other OECD countries, including other Nordic countries with the exception for Finland (Erlandsen and Lundsgaard 2007, Figure 17, Hüfner 2007, 7). Deregulation continued in Sweden under minority social democratic governments 1994-2006, primarily supported in Parliament by the Green Party and the Left Party. In 2003, Sweden and the other Nordic countries excluding Norway were, together with the Anglo-American countries, the most deregulated economies in the OECD. ${ }^{4}$ Sweden was also an early mover in permitting private provisions of collective services such as health, children and elderly care and education. In the late 1990s and the 2000s, the production of welfare services in Sweden was still predominantly organized by the public sector (Erlandsen and Lundsgaard 2007, 26, 38). But the share of private (independent) schools at the upper secondary level increased dramatically in these decades, from 10.9 percent 1995/1996 to 48.2 percent 2010/2011. Today (the academic year 2010/2011) private schools enroll 23. 8 per cent of the students at this level (Ekonomifakta 2011, Swedish National Agency for Education 2011, Table 4A).

In the 1990s and 2000s deregulations also affected the Swedish labour market. (We also include under this term changes in the social insurance system affecting the wage floor.) The unemployment benefit ratio was reduced from 90 per cent to 80 per cent under the centre-right coalition government 1991-1994. The social democrats made a further reduction in unemployment benefits in 1995 (to 75 per cent), but they restored the initial

\footnotetext{
${ }^{4}$ See Erlandsen and Lundsgaard 2007, Table 18. According to the OECD index, in 2008, product deregulation in Sweden was only slightly above the OECD average and less than that of the other Nordic countries including Norway (see Wölfl et al. 2010, 7-8). The change in Sweden's deregulation status between 2003 and 2008 probably reflected the revision of the indicator system rather than real changes.
} 
(centre-right) level (80 per cent) in 1997. In 2001, the social democrats differentiated the compensations by raising the benefit ceiling in the beginning of the unemployment period and reducing it after a certain time lapse (20 weeks). But the ceiling on earnings eligible for unemployment benefits reduced the overall effective replacement ratios from the early 1990s to the mid-2000s (see Bennmarker et al. 2007, 89-90). Furthermore, the present centre-right coalition has introduced an unemployment benefit system where the benefit levels are reduced from 80 to 70 per cent and finally to 65 per cent with the duration of unemployment. Finally, the ceiling 18700 SEK per month remained unaltered. This disconnected the unemployment benefit from earlier income for the majority of the population. (The average income for full time work in Sweden was 25800 per month in the mid-2000s.) In the 2000s, the Nordic countries except Sweden were in the group with the most generous unemployment benefits in the OECD although there was a drastic reduction in the Norwegian unemployment net benefits in 2008 (OECD database, Net replacement rates (NRR) over a five-year period following unemployment, 2001-2009, OECD 2009, Table 1.6).

Furthermore, the present centre-right government in Sweden has reduced the sickness compensation. A reduction in the ceiling from 33000 SEK per month to 25000 SEK per month in October 2006 was a challenge to the principle of income-related compensations in the Swedish welfare system. The government also reduced the benefit ratio from 80 to 75 per cent after $11 / 2$ year of sickness. There was also a time limit, $2 \frac{1}{2} 2$ year, in the new system. In 2010 the majority of people who were still sick after $2 \frac{1}{1} 2$ year entered an ALMP program called the Job and Development Guarantee where the compensation rate 
is 65 per cent.

Job security was also reduced in Sweden in the 1990s and 2000s. The Job Security Act of 1994 was in fact a break with the 1938 Saltsjöbaden Agreement. The Agreement stated that labour conflicts, e.g. over wages and job security, should be resolved by collective bargaining, not by non-neutral legislation. The Job Security Act entailed that the last recruited employees must be dismissed first. The non-socialist government decided in 1993 to exclude two wage earners from the principle of "last-in first-out". This exclusion was immediately abolished by the following social democratic government. But in 1996 the social democrats allowed short-term employment contracts as an exception from the Act. Further exceptions were made under the social democratic government in 2001 due to a short-lived parliamentary alliance between the Green Party and the centre-right parties - the exemption of two persons from the "last-in first-out" principle was reintroduced in firms with less than ten employees. Finally, notwithstanding the commitments to job security by the largest party in the centre-right coalition from 2006 (Moderata Samlingspartiet), the possibilities for employers to hire temporary workers were extended (in 2007). According to a OECD measure, among the member countries, only the Mediterranean countries had more job security than Sweden in 1990. In 2008, job security in Sweden had fallen below the OECD average and was e.g. lower than that in Norway and Finland. Swedish job protection was particularly low for temporary workers (OECD database Strictness of Employment Protection). Besides, the Job Security Act is a dispositive law, thus it can be revoked by local agreements between the companies and the trade unions. 
Thus, the new economic-policy regime in Sweden in the 1990s and 2000s was constituted by a deregulation of financial, labour and product markets and a departure from Keynesian discretionary economic policies. But these features of a new regime were combined with some reminiscences from older economic-policy routines. It may be legitimate to refer to a Swedish version of the new consensus on economic policy encompassing ALMP measures and "voluntary" incomes policy.

From the late 1950s to the early 1970s Swedish economic (and wage) policy was inspired by the Rehn-Meidner model. The model advocates restrictive macroeconomic policy over the business cycle (in the medium term), e.g. to provide space for expansionary fiscal policies in a (deep) recession, wage policy of solidarity and ALMP programs. In the case of ALMPs, the founders of the model referred to selective (instead of aggregate) stimulus of labour demand, including regional policy, but primarily to supply and matching oriented measures in labour markets. In order to improve the matching process the RehnMeidner model further recommends high unemployment benefits (Erixon 2010, 679681). The macroeconomic policy of the model was not fully applied in the postwar period. But the breakthrough of ALMPs in Sweden in the late 1950s was legitimized by the founders' argument that these measures would result not only in low unemployment (and equity) but also in low inflation and structural change. The Rehn-Meidner model is similar to the Danish flexicurity model advocated by the EU commission in the late 2000s. The macroeconomic policy of the Danish flexicurity model is unclear. Moreover, the model's view of coordinated central wage bargaining may differ from that in the 
Swedish model. In the Rehn-Meidner model wage coordination is a necessary condition for solidarity wages, thus for attaining uniform wages for similar work.

There was a strong emphasis on ALMP projects in Sweden also in the 1990s and 2000s. In fact, there is no parallell in other periods to the expansion of ALMPs under the centreright government in 1991-1994. In 1994, 7.3 per cent of the total labour force was engaged in ALMP programs. During the 1992-1997 period ALMP expenditures as a share of public total expenditure and GDP was higher in Sweden than in any other OECD country especially after adjustment for the rate of unemployment. Through the strong support from the political parties, the central labour-market organizations and the electorate and through the expansion of the National Labour Market Board (AMS) in the 1960s and 1970s ALMP measures had largely been institutionalized in Sweden.

"Voluntary" incomes policy is another reminiscence of an older economic-policy regime in Sweden in the 1990s and 2000s. True to the 1938 Saltsjöbaden Agreement wage restraint by trade unions showing concern about macroeconomic stability is the typical incomes policy arrangement in Sweden in the postwar period. Social scientists consider the absence of compulsory (legislative) incomes policy as a unique Swedish feature even in a Nordic perspective (see Vartiainen 2011). In the early postwar years wage moderation by central trade unions was an essential component of a Keynesian strategy to combine expansionary fiscal and monetary policy measures aimed at full employment with price stability and external balance (under fixed exchange rates). In the 1980s, wage 
restraint was also expected to stimulate employment by its positive effect on Swedish market shares.

Swedish "voluntary" incomes policy in the postwar period did not exclude that labour market organizations were under strong pressure from governments and public agencies to accept moderate wage increases. Furthermore, tripartite negotiations about wages (and taxes) took place under exceptional conditions in the 1970s and 1980s, first after OPEC I (the so-called Haga agreements) and then in the boom of the 1980s (the so-called Rosenbad rounds). In the latter case, informal discussions between central trade unions and the social democratic government in the mid-1980s defined a wage ceiling that was soon broken by market-induced local wage increases, so-called wage drift. The most obvious departure from the Saltsjöbaden Agreement occurred at the highest point of overheating (1990). The social democratic government proposed an income-policy arrangement including price and wage freezes and also a ban on strikes. But the proposition was rejected in Parliament leading to a government crisis and the resignation of the Minister of Finance, Kjell-Olof Feldt.

Between the mid-1950s and the mid-1980s coordinated wage agreements between the Confederation of Swedish Enterprise (Svenskt Näringsliv, formerly SAF) and the white collar and blue collar organizations respectively were conditional for Swedish incomes policy. Since 1983, central wage increases have been determined, with some exceptions, at the industry level. In the deep recession of the early 1990s central labour market organizations agreed to follow the recommendations of low wage increases by a newly 
appointed government wage committee, the so-called Rehnberg commission. The social democratic government had plans in the mid 1990s to make a more definitive departure from "voluntary" incomes policy by tripartite wage negotiations. The combination of industrial central agreements and the depreciation of the SEK had prompted high nominal wage increases in export industries. (Profits' share of value added in Swedish manufacturing rose to record levels for the postwar period in the mid-1990s.) However, "voluntary" incomes policy was integrated in the new stabilization-policy regime by an agreement between the employer organizations and the trade unions in manufacturing.

The so-called Industrial Agreement in 1997 embraced both white collar and blue collar workers in manufacturing. From 1998 to 2010 wage agreements in manufacturing were made for three-year periods. These agreements have correspondences in other parts of the Swedish labour market. But they were expected to serve as a wage norm for other sectors making it possible to internalize negative wage externalities at the industrial level in the Swedish case. Through the set up of governmental wage mediation body in 2000 (Medlingsinstitutet), all institutions for incomes policy in the new Swedish economicpolicy regime were installed.

The labour-market partners in Swedish manufacturing have officially declared that they are following the wage norm of wage increases at a European level in order to maintain Swedish competitiveness. But public agencies have replaced this rather anachronistic wage norm under the new economic-policy regime with a recommendation that wage increases must be compatible with the Central Bank's inflation target. The National 
Institute of Economic Research (Konjunkturinstitutet) maintains that collective wage setters can reduce equilibrium unemployment provided that the (short run) wage increases do not threaten the Central Bank's inflation target (National Institute of Economic Research 2011, 8-9).

Thus the Swedish incomes policy of the 1990s and 2000s shared the idea with the incomes policy of the 1980s that wage restraint has a positive effect on employment. But the suggested underlying mechanisms differed. In the 1980s, high nominal wages were expected to lead to losses of market shares and therefore to lower employment unless the government devaluated the SEK or pursued an expansionary fiscal policy. In the early 1990s, these last resorts were excluded by the explicit hard-currency policy. The adherents of this policy also emphasized that high nominal wages would reduce employment by inducing increases in the long-run interest rate reflecting a weaker confidence in the SEK. In the present economic-policy regime, employment will be reduced by a restrictive monetary policy if wage setters are shooting above the inflation target. With flexible exchange rates the competitive strength of the exposed sector could possibly have been restored by depreciations.

\section{Living in the shadow of a deep crisis and other bad experiences}

The change in Swedish economic policy in the 1990s cannot be understood without references to the deep economic crisis at the beginning of the decade. The fall in Swedish GDP growth in 1991-1993 was larger than that during the Great Depression in the early 
1930s. ${ }^{5}$ And the employment decline was the largest ever in the history of Swedish industrialism (Edvinsson 2005, Table 9.7 and 9.12). Furthermore, Sweden, famous for its ability to sustain full employment during the turbulent years of the 1970s and 1980s, experienced an increase in open unemployment from 1.7 per cent in 1990 to 9.3 per cent 1994, a rate only 1.5 percentage points lower than the EU average according to standardized OECD data. And there was no decrease in Swedish unemployment until autumn 1997. Thus, Sweden, the very example of full employment, had entered the road to mass unemployment although the rate was much lower in Sweden than in Finland in the 1992-1997 period (see Table 1* in Appendix 2). Moreover, during the first half of the 1990s, there was a dramatic decline in labour force participation rates, although from a high level, in Sweden. This decline primarily reflected an increase in early retirement and long-run participation in ALMP programs.

Sweden's change to flexible exchange rates in November 1992 is partly explained by the globalization of financial markets leading to strong speculations against the SEK in a situation where financial actors thought that its value was too high. But the depth and also the timing of the economic crisis in Sweden, occurring in a period of turbulent global financial markets, explain the sudden change to flexible exchange rates in the country. The currency crisis in Sweden in November 1992 was triggered by the combination of strong recession tendencies, a bank crisis and a rapidly increasing public deficit. In Denmark and Norway, the recession was earlier (in the 1980s) and milder than in Sweden

\footnotetext{
${ }^{5}$ In 1990-1992, Sweden fell from the 6th or 8th to the 16th position in the ranking of OECD countries in terms of GDP per capita levels (there are two PPP measures). Sweden has not yet regained its former position in the economic "welfare league". In 2010, Sweden was ranked number 10 among the OECD countries (on both PPP measures), see OECD database, Purchasing Power Parities for GDP and related indicators.
} 
and Finland. And Denmark did not experience any financial crisis at all. These Nordic differences must be an important part of the explanation of why Denmark chose to keep a system of fixed exchange rates, while Norway changed to flexible exchange rates one month later (in December), and then returned to fixed exchange rates already in May 1994 (although the new Norwegian system provided room for corrections of the exchange rate). In Norway, inflation targets were not introduced until 2001. Finland, that experienced the worst recession and bank crisis among the Nordic countries, had already switched to flexible exchange rates a few months earlier than Sweden. In fact, the change to flexible exchange rates in Sweden were not initially considered by the non-socialist government or the Central Bank as a component of a new economic-policy regime but as an exceptional measure during an economic crisis. The country should return to fixed exchange rate once the value of the SEK had been adjusted downward and the crisis was over.

By contributing to the large deficit in the public budget the deep recession in the early 1990s was also important for the very restrictive fiscal policy in Sweden in the middle of the decade. The fact that there is no parallel to this fiscal policy in other OECD countries until to the Great Recession 2008-2010 indicates that Swedish economic policy in the 1990s was shaped by the depression at the beginning of the decade. The crisis also reinforced the negative view among Swedish politicians and economic experts of past economic policies. The conventional wisdom in the 1990s was that exchange-rate and fiscal policies in the 1970s and 1980s had been too expansionary (or not restrictive enough) contributing significantly to inflation and overheated financial and housing 
markets. Thus, despite the fact that mainstream macroeconomics have difficulties explaining overinvestment and financial bubbles, Swedish decision makers and their economic advisors suggested that the sources of the crisis in the early 1990s could be found in 1980s. They conjectured (probably correctly) that the deep crisis in the early 1990s was not primarily the consequence of contemporary negative demand shocks but of positive demand shocks in the 1980s.

Overheating and inflation in the 1980s and the following deep recession in the early 1990s (e.g. influencing the conventional view of the earlier economic policies) can also explain why fiscal rules were implemented in Sweden but not in all OECD countries and why these rules were stricter or introduced earlier in Sweden than in other OECD countries. Fiscal targets were not introduced at all in, for example, Denmark, a country that had not experienced any public budget or financial crisis in the late 1980s and early 1990s. Empirical evidence that fiscal rules were endogenous rather than prime driving forces behind fiscal policy in the OECD countries (OECD 2007, 220) underpins the hypothesis that the Swedish budget crisis in the early 1990s was decisive for the implementation (and timing) of fiscal rules in the country. Furthermore, Sweden's history of high inflation and the crash landing of the economy in the early 1990 s contributed to the strong priority of price stability in the country in the 1990s and 2000s manifested by the Central Bank reform (cf. Hayo and Hefeker 2001, Daunfeldt and de Luna 2008) and the restrictive monetary policy in the country given its inflation target (see the section "Was Swedish macroeconomic development caused by the new economic-policy routine?" below). 
Furthermore, extensive regulation of product market and services in Sweden during the first half of the 1990s must be seen against the background of the deep recession at the beginning of the decade. A plausible hypothesis is that the recession created "a crisis consciousness" and focus on short-run macroeconomic problems in the debates on economic policies that facilitated the introduction of radical structural reforms. This hypothesis is supported by the fact that deregulation in the first part of the 1990s was more radical in Sweden and Finland than in other OECD countries including Norway and Denmark. Another plausible hypothesis is that Swedish deregulation reflected the country's poor growth performance in the 1970s and 1980s. Economic experts saw deregulation as a necessary device to increase productivity and GDP per capita growth after a period with a Swedish growth lag behind other OECD countries (Productivity Commission 1992, Lindbeck 1997).

\section{New economic thinking}

The fact that a new economic-policy regime was also introduced in countries without any deep recession at the beginning of the 1990s and with various experiences of economic policy in the preceding decades indicate that theoretical and ideological factors mattered (see Blyth 2001). What is more, in Sweden, new economic thinking about the limitations of discretionary Keynesian policies shaped the decision makers' view of past economic policy. The devaluations and high inflation in Sweden in the 1980s were probably a salient explanation for speculators' mistrust in the SEK in Autumn 1992. But it can be 
argued from the abandoned Keynesian perspective that a more ambitious countercyclical fiscal policy (and revaluation of the SEK) could have prevented overheating in Sweden during the second half of the 1980s. And after all, Swedish inflation was only systematically above the OECD average in the $1988-1991$ period. ${ }^{6}$ What is more, the victory of new economic ideas obscured that the public budget crisis in the early 1990s would have been milder if Sweden had followed the Rehn-Meidner recommendation of a restrictive fiscal policy in the medium term (which had called forth a more restrictive fiscal policy in the 1980s). And it could have been maintained on Keynesian grounds in the early 1990s that high inflation was the price that must be paid to achieve very low rates of unemployment in Sweden in the 1980s.

When explaining the shift to a new economic-policy regime in Sweden our emphasis is on theory rather than on ideology. ${ }^{7}$ The new neoclassical synthesis (consensus) in macroeconomics is based on the theory of rational expectations and the neo-Keynesian theory about wage and price rigidities (or imperfections on capital markets). Advocates of the new synthesis use concepts such as NAIRU and the natural rate of unemployment (or equilibrium unemployment) to underline that rational expectations undermines most attempts to affect employment by changes in aggregate demand. It is even more unlikely

\footnotetext{
${ }^{6}$ In fact, in 1985-1991, that is in period of severe Swedish overheating, the difference between Swedish and (West-)German interest rates fell from above 8 per cent (short-run interest rates) and 6 per cent (longrun interest rates) to approximately 2 per cent (both interest rates). Moreover, on unclear grounds, the gap between Swedish and German long-run interests more than halved from the end of 1990 to Summer 1992, immediately before the Swedish currency crisis.

${ }^{7}$ Our main argument for downplaying the role of ideology is that there was no substantial difference in the support for the new economic-policy regime during the 1990s and 2000s between the non-socialist parties and the social democrats in Sweden (see further above). What is more, the new regime was also introduced in Finland, a country without any neoliberal ideological offensive in the 1980s. The notion of neoliberalism will be avoided above notwithstanding the arguments for considering new macroeconomics as a new ideological basis for economic policy.
} 
that this will be possible in the medium term. It is in any case bound to generate accelerating inflation. Fiscal policy may have long-run effects on production and employment (by its effect on interest rates) but monetary policy is neutral. The neutrality of money makes it unnecessary and even harmful to establish targets for the Central Bank in terms of employment and GDP. In this theoretical perspective the most important task of economic policy in the medium and long term is to control inflation expectations and create favourable conditions for investments, e.g. by maintaining stable inflation.

Furthermore, structural reforms aimed at improving the functioning of labour and product markets are the only feasible way of maintaining very low rates of unemployment. The neo-Keynesian element in the new consensus guarantees a room for macroeconomic policy interventions. But the neo-Keynesians are not abandoning the assumption of rational behaviour or the recommendation of structural measures to make product and labour markets more flexible.

There are some weaknesses and inconsistencies in the new neoclassical synthesis. The role of fiscal policy in stabilization policy is uncertain, especially in relation to fiscal rules. Moreover, the proposition that aggregate demand has no effect on GDP and employment levels in the medium can be questioned by reference to the StockholmWicksellian theory of cumulative disequilibrium processes when nominal interest rates are rigid. This theory has in fact its parallels within new macroeconomics. Negative demand shocks or restrictive fiscal policies may lead to higher real interest rates (because of possible reductions in expected inflation and sluggish nominal interest rates), and this would have durable negative effects on production and employment levels (Blanchard 
2011, 470-473). In transitional phases of economic policy making, situations in which the goal is to reduce inflation expectations, the new neoclassical synthesis may face critical changes in production and employment. For example, the restrictive fiscal policy of the Swedish social democrats in the mid-1990s was indeed a risky venture from a medium (and long) term perspective. What is more, restrictive monetary policy measures to fight inflation may reduce employment and production in the medium and long term if people are not fully rational. The trade-off between inflation and unemployment (the Phillips curve) seems to exist in e.g. the United States and Sweden at low rates of inflation (see Akerlof et al. 2000, Lundborg and Sacklén 2006). Inflation targeting as the only mediumterm strategy can in fact be questioned with reference to the neo-Keynesian assumption of price and wage rigidities. Neo-Keynesian theories (and empirical studies) shed light on the possibility of long-run employment and production effects of demand shocks and economic policy when prices and wages are inflexible. Furthermore, the obvious goal conflict in economic policy between output stabilization and inflation in the case of negative supply shocks makes it reasonable to argue for the coordination of monetary and fiscal policy. A social welfare function weighting inflation against unemployment should arguably be defined by the political system, not by the Central Bank (see the Bent Hansen-Jan Tinbergen goal-mean analysis).

The new macroeconomic ideas were adopted by some leading Swedish politicians and their experts already in the early 1980s. The Budget Bills of the social democratic government emphasized the need to reduce inflation expectations in the Swedish economy (Erixon 2010, 690, 710, n 18). The Ministry of Finance primarily referred to 
price and wage expectations in Swedish product and labour markets. Leading social democrats and their economic advisors were particularly influenced by a report from some Swedish economists in the mid-1980s arguing for norms in economic policy. These economists emphasized the negative experiences of Swedish "accommodation policies" and the need for measures to reduce inflation expectations by strengthening confidence in fixed exchange rates (Tson Söderström et al. 1985). By reference to the Productivity Commission 1989-1991 the "norm economists" also assumed that devaluations (and reductions in payroll taxes) would hamper economic growth (Tson Söderström et al. 1991, 13-14, 49-53). The Productivity Commission had argued for stronger transformation pressure to overcome Sweden's productivity growth lag. The recommendations by the norm economists became an important guideline for the centreright government along its "One Way" (see Wibble 1992).

The inflation target established in 1993 demonstrated that Swedish economic policy was still governed by norm thinking after the abandoning of fixed exchange-rates as an anchor. Moreover, the Budget Bills under the social democratic government referred explicitly in the mid-1990s to the NAIRU and the equilibrium rate of unemployment and to the necessity of making structural reforms in the labour market. The Ministry of Finance agreed with leading academic economists that the equilibrium rate of unemployment was above the actual rate at the end of the 1980s and also increasing during this decade because of higher replacement ratios and less wage coordination. The ministry also shared the OECD view that the equilibrium rate of unemployment had increased (for unclear reasons) to at least 4-5 per cent during the first half of the 1990s 
(Ministry of Finance, Revised Budget Bill 1995, appendix 1.1, 91, Budget Bill 1996, appendix 1,38). However, the reduction in the replacement rate in the unemployment insurance system in the mid-1990s was primarily a part of the budget consolidation policy (Ministry of Finance, Revised Budget Bill 1995, 31).

In the mid-1990s, the social democratic government emphasized like the Central Bank the need for measures aimed at reducing inflation expectations. The Budget Bills, the socalled convergence program (Ministry of Finance 1995) and the government's proposal for growth policy in 1995 (Government Proposition 1995/96, 25) assumed in line with new macroeconomics that a restrictive fiscal policy would lead to lower inflation expectations and also to higher economic growth and permanently higher employment levels.

The notion of time-inconsistent political decisions (for example, politicians are willing and able temporary to reduce unemployment by demand management if economic agents are not fully informed) was pivotal in the new neoclassical consensus. The notion was also central in the new political economy, the second theoretical pillar of the new economic policy in e.g. Sweden in the 1990s. According to the political business-cycle theory politicians pursue an expansionary economic policy (and postpone measures to fight inflation) ahead of an election, hoping for re-election. In the (new) partisan theory politicians falsely believe that they can make trade-offs between inflation and unemployment (see the theory of rational expectations). Swedish macroeconomists referred to these theories when arguing for central-bank autonomy and also for fiscal 
rules. The new political economy was the theoretical base for the public committee working out the proposal of an independent Central Bank with price stability as the superior objective (see SOU 1993:20, appendix 2).

The third theoretical pillar of the new economic-policy regime in Sweden was the wage bargaining, trade union and efficiency-wage theories of modern macroeconomics determining the equilibrium rate of unemployment. These theories agree that market forces are peripheral or only indirectly of importance for the equilibrium wage rate. On the other hand, by pointing to shifts in the "wage-setting" function, bargaining and tradeunion theories legitimate incomes policy solutions such as the Industrial Agreement. Furthermore, these theories support the conclusion that equilibrium unemployment can be reduced by cuts in unemployment benefits. If, alternatively, stock-flow matching models (with heterogeneous workers and jobs) had been more influential in Swedish economics in the 1990s and 2000s, collective wage agreements and incomes policy would have played a more subordinate role in the new economic-policy regime, while policy measures aimed at increasing labour market flexibility would have been more important. Some economists have formulated search models showing that unemployment would be reduced by lower replacement ratios, but this conclusion is based on a large number of restrictive assumptions (cf. Pissarides 1986).

The "age of economism" culminated under the present centre-right coalition government. The new policy orientation of the leading party in the coalition, Moderata Samlingspartiet, was based on all theoretical pillars attributed to the new approach to 
economic policy above. For example, the party emphasized the crucial role of central trade unions in incomes policy, a clear break with the "One Way" in the early 1990s. The Minister of Finance Anders Borg, were strongly influenced by the neoclassical synthesis and the other two pillars of modern macroeconomics. His belief was probably strengthened by empirical studies showing that high labour taxes and high unemployment benefits had positive effects and job security more modest or ambiguous effects on unemployment. $^{8}$

\section{Did the colour of the government matter?}

The arguments by "the new moderates" (see Moderata Samlingspartiet) in the mid-2000s for collective wage agreements, job security laws, labour market policies (primarily employment subsidies and matching services), tax-financed welfare programs and full employment indicate that there was still an ideological hegemony for social democracy in Sweden. Some central features of the party's successful new strategy were compatible with their old strategy along the "One Way", especially the reductions in income taxes, but the arguments differed. The new moderates did not argue for tax cuts directly in terms of economic growth. Instead, by taking over the concept "the work line" from the social democrats they argued for effective measures aimed at increasing the employment rate. But the social democrats had obviously lost its political hegemony in the 1990s and 2000s.

\footnotetext{
${ }^{8}$ See e.g. Nickell et al. (2005). It was not risk free to base an economic-policy strategy on cross-country econometric studies from the 1990s and early 2000s. The results from these studies were later questioned on methodological grounds. At the same time, there were restrictions on the centre-right support for economism - the government largely abandoned those property taxes that are almost unanimously supported by economists.
} 
The loss of political hegemony of the social democrats in the 1990s and 2000s seems not to have been salient for the change in Swedish economic policy. The financial markets had been deregulated under social democratic governments in the 1980s. In 1993, the social democrats opposed the non-socialist radicalization of their former decision to permit private employment services. Centre-right parties predominantly ruled Sweden and Finland in the first half of the 1990s, a period with radical deregulation of the goods and service sectors. But the Swedish deregulation of product markets had been started by the social democrats in the early 1990s, they had also executed or accepted the bulk of the non-socialist proposals in the 1991-1994 period. Product and financial markets had also been deregulated in Norway from the late 1980s to the mid-1990s, with the social democrats in office. The pragmatic acceptance of such policies by the Nordic social democrats (and the centre-right coalition parties in Finland) indicates that ideology was not decisive for the deregulation of financial and product markets in the Nordic countries in the 1980s and 1990s. But the enthusiastic support for deregulation (including privatization) by Moderata Samlingspartiet (the leading non-socialist party) on ideological grounds influenced the orientation and perhaps also the scope of productmarket deregulations in Sweden in the 1990s.

In Sweden, the non-socialist parties (including the Green Party) seemed more prone to make exceptions from the legislation on job security than the social democrats. But exceptions were also made by a social democratic government (1996). The hypothesis that centre-right parties are more willing to give up job security than the social democrats 
is refuted by the new policy of Moderata Samlingspartiet, the dominating party in the present centre-right coalition. Moreover, in the mid-1990s, unemployment benefits were reduced by a social democratic government. ${ }^{9}$

Inflation targeting and the consolidation of an independent Central Bank under a nonsocialist government were immediately accepted by the social democrats. What is more, a social democratic government embarked on a very restrictive fiscal policy, despite high unemployment, in the mid-1990s. The budget consolidation was supported in Parliament first by the Left Party (Vänsterpartiet) and then by the Centre Party (Centerpartiet). And it was a social democratic government that imposed various restrictions on fiscal policy, restrictions that were only opposed by the Left Party. The social democrats simultaneously declared a war against neo-liberalism. But the party have accepted, and even initiated, the introduction of the new economic-policy regime.

Thus, deregulation and especially the new macroeconomic policy in Sweden in the 1990s and 2000s, can hardly explained by the shift in the political power balance in favour of parties to the right of the social democrats. ${ }^{10}$ Leading social democrats also supported the idea that the public sector became too large in the 1980s. The share of public expenditure and taxes in GDP was reduced by social democratic governments in the 1990s and 2000s. There ambition was to provide more room for private provisions of child care, elderly

\footnotetext{
${ }^{9}$ However the social democrats partly restored the former unemployment benefit ratios in 1998 when the public budget was in balance again (and an election was approaching) and they opposed the exceptions to the Job Security Act decided by Parliament in 2001.

${ }^{10}$ There was also a strong consensus in Swedish politics in the 1990s about the need for a new supplementary pension system. The new system introduced in 1998 was a political compromise between all parties in Parliament excluding only the Left Party.
} 
care, education and health. But the social democratic resistance to the tax reductions and privatization of state-owned companies suggested by the current centre-right government shows that the size of the public sector and deregulation remains a major cleavage line in Swedish politics.

While in the 1930s and the early postwar period, the social democrats had formulated alternatives to established economic ideas and policies, they failed to do so in the 1990s and 2000s. In opposition 1991-1994 the social democrats had first advocated expansionary fiscal policy measures in order to fight unemployment. But they abandoned this "orthodox" Keynesian policy immediately before the 1994 election. The main independent contribution to economic policy by Swedish social democracy in the 1990s and 2000s was the strong priority to higher education in the mid-1990s and the launching of the so-called Knowledge Lift (Kunskapslyftet) 1997-2002, an extensive program providing education at the upper secondary school level to people with primary education only. The Knowledge Lift involved 10 per cent of the labour force during the first four years. However, with the exception for these measures in the boarder land between education and economic policy, Swedish social democracy was an assimilator rather than initiator of new ideas about economic policy in the 1990s and 2000s. ${ }^{11}$

\footnotetext{
${ }^{11}$ The newly appointed Prime Minister Göran Persson formulated in 1996 a green political vision, aiming to combining high economic growth with demanding environmental standards. This ideological renewal by the social democrats had, however, no significant effect on Swedish economic policy, including industrial policy, in the following years.
} 


\section{From power groups to vested interests}

One reason for the social democratic loss of initiative in Swedish economic policy was the gradual marginalization of LO, the confederation of blue-collar workers. LO had had an exceptional impact on Swedish economic policy under social democratic governments in the postwar period until the mid-1970s (Erixon 2010, 684-685). This influence weakened in the 1970s and 1980s and had disappeared in the 1990s. Unlike earlier, decisions on deregulation of financial markets in the 1980s and the tax reform 1990-1991 were not been based on consultations between the LO and social democratic leadership. ${ }^{12}$ LO was critical but could not prevent deregulation (including financial markets deregulation in the 1980s), exceptions from the Job Security Act or changes in the social insurance system (such as reductions in the unemployment benefits). ${ }^{13}$ And LO was not the initiator of the new macroeconomic policy. LO economists had advocated flexible exchange rates since the late 1980s, but their position had no decisive influence on the Central Bank's decision (sanctioned by the centre-right government) to float the SEK in November 1992. And at that time, LO did not recommend that flexible exchange rates should be combined with inflation targeting.

The LO influence on economic policy certainly ceased when the golden age of the Social Democratic Party was over. But the loss of social democratic hegemony in politics only partially explains LO's loss of influence on economic policy. In the mid-1990s, even a

\footnotetext{
${ }^{12}$ Interview with the LO Chief Economist P.-O. Edin (Book 1997, 37). It should be added that LO neither had any influence on the social democratic "Third Way" policy in the 1980s.

${ }^{13}$ However, the pressure from LO is one of the reasons why the social democratic government in 1998 raised the unemployment benefit ratio back to the ratio enacted just before the start of its budget consolidation policy.
} 
social democratic government would regard LO as one among several special interest groups and no longer as an important initiator and partner in economic policy. The new relation between the social democrats and LO in the 1990s was the result of political decisions and economic developments in the 1970s and 1980s.

LO's radical proposal of wage earner funds financed by profit taxes in the mid-1970s became a political burden for the organization and also for the social democratic party in the subsequent decades. A watered-downed version of wage earner funds without the original ambition of changing power relations and ownership in the Swedish business sector was introduced in 1983. But these funds were quickly abolished by the centre-right government (in 1992). Furthermore, misplaced advice from LO contributed to Swedish overheating in the 1980s. Economic policy was at stake in the "war of roses" between the social democratic government and LO during the 1980s. ${ }^{14}$ LO opposed government plans to cool down the overheated Swedish economy by higher indirect taxes. The resulting failure to tighten fiscal policy sufficiently was a Pyrrhic victory for LO. In the 1990s the organization considered it a big mistake.

Undoubtedly, the wage-earner fund radicalism and the "ultra-Keynesian" policy recommendations weakened LO's influence on economic policy in the 1990s even under social democratic governments. At the same time, $\mathrm{LO}$ - together with member unions in the exposed sector - eventually tried to demonstrate "responsibility" by sanctioning compulsory incomes policy in 1990. This stirred up strong internal tensions within LO.

\footnotetext{
${ }^{14}$ The growing skepticism regarding nuclear power among leading social democrats in the late 1970s and 1980s was also a source of a split between the party and the LO unions organizing wage earners in the exposed sector.
} 
The proposal was primarily resisted by the trade unions in the public sector. LO unity had already been challenged by the devaluations and by the change from coordinated to industrial wage negotiations in 1983. Separately or in interactions these factors caused a development towards larger wage gaps (cf. Gustavsson 2008). In the 1990s and 2000s, industrial wage negotiations (including the Industrial Agreement) created tensions mainly between the LO trade unions inside and outside the manufacturing sector.

Industrial wage negotiations (with some exceptions) from the mid-1980s reduced the role of LO in wage formation to that of an informal coordinator of blue-collar wage claims. From 1956 to 1983 LO was a central agent in coordinated wage negotiations between the central employer organization SAF and the blue-collar unions. In the mid-1990s, the organization failed to become a central actor in a reconstructed system of coordinated wage bargaining focusing on incomes policy (Edin Group 1995). Instead, the parties to the Industrial Agreement became the main actors when incomes policy was incorporated in the new economic-policy regime (see the Industrial Agreement). The change from coordinated to industrial wage agreements reduced LO's influence on incomes policy but also on economic policy in general. ${ }^{15}$ What is more, the increasing influence of economic experts since the 1980s (see next section) was largely at the expense of LO.

Thus, non-socialist governments, controversial LO positions, internal conflicts (e.g. through the social democratic "Third Way" policy in the 1980s), decentralized wage

15 In 2008-2009, LO also failed in its ambition to reach an agreement on labour relations - similar to the 1938 Saltsjöbaden Agreement - with The Confederation of Swedish Enterprise (Svenskt Näringsliv, formerly SAF) and the cartel of white-collar unions (PTK). The negotiations broke down because LO and Svenskt Näringsliv were too divided on the issue of job security. 
bargaining and the power of experts were factors behind the declining LO influence over Swedish economic policy in the 1990s and 2000s. Another explanation of LO's peripheral role in Swedish economic policy-making through these decades was the higher unemployment, which reduced the general strength of labour. In addition, the global shift of labour demand in favour of skilled labour and private service sector jobs was unfavourable to LO. Wage earners in ICT industries and dynamic private service sectors were largely organized by trade unions outside LO, they were also generally less organized. In the 1990s and 2000s, there was a substantial decrease in union density in Sweden although from a high level in an international perspective. The unionized workers' share of employees shrank steadily from 83 per cent 1990 to 71 per cent 2008, remaining stable 2008-2010 despite a deep recession (Kjellberg 2010). The reduction in union density accelerated during the present centre-right coalition (from 77 in 2006 to 73 per cent in 2007) because of higher individual fees in the unemployment benefit system, especially for workers in industries with a high risk of unemployment (manufacturing), and the elimination of tax deductions for membership in trade unions and unemployment insurance funds.

The marginalization of LO in the 1990s and 2000s had actually no parallels in other Scandinavian countries. Norwegian LO actually strengthened its position through these decades; Norway is the only Western country where the influence of a central blue-collar union organization on economic policy today can be compared to that in Sweden in the early postwar period. The decentralization of wage negotiations to industrial and local levels, and increasing inclination to distribution of centrally determined wage increases at 
the local level, was probably more accentuated in Sweden than in the other Nordic countries in the 1990s and 2000s. Furthermore, Denmark had experienced increasing unemployment already in the 1970s and actually a declining rate in the 1990s. Moreover, Norwegian unemployment never approached the high Swedish rate in the 1990s.

Facing the decline of its strength, LO gradually turned to support the new economicpolicy regime. In the early postwar period, LO had formulated a successful alternative economic policy model (the Rehn-Meidner model). Now, the organization failed to come up with alternatives. Despite protests particularly from public sector member unions and rank-and-file, LO did not oppose the very restrictive fiscal policy by the social democrats in the mid-1990s. The organization gradually accepted the independence of the Central Bank, the rules for fiscal and monetary policy and the underlying new macroeconomic theories (LO 2008). LO criticized the Central Bank for pursuing a too restrictive monetary policy during the first half of the 2000s, but only in relation to the inflation target. Faced with a fait accompli, LO also in due course approved the deregulation of the Swedish economy with the exception of the changes in the social insurance system under the current centre-right coalition. Thus, LO has largely accepted the new economicpolicy regime. $^{16}$

But the weaker influence of LO on Swedish economic policy in the 1990s and 2000s was not matched by a growing influence of capital interests. The Confederation of Swedish

\footnotetext{
${ }^{16}$ In fact, the LO economists accepted the neo-Keynesian theory that recessions are caused by wage rigidities (LO 2008). At the same time they advocated the structural policy of the Rehn-Meidner model. Recently, the LO chief economist has emphasized the model even more strongly, urging the social democrats to use an up-dated version (see Westerlund 2011).
} 
Enterprise, Svenskt Näringsliv, was not a central actor when Sweden introduced flexible exchange rates, central bank independence or fiscal and monetary targets. ${ }^{17}$ With the possible exception for the campaign for Swedish membership in the EU and EMU, Svenskt Näringsliv and the large multinational companies kept a low profile in the discussions about economic policy in the 1990s and 2000s. Managers and owners of the companies did express their negative view of the economic policy during the social democratic party's first term in office (1994-1998). But at the end of the period they focused on the uncertain future of nuclear power, the tax collection system, the financing of the social security scheme and certain peripheral taxes (see värnskatten below). They were not concerned with crucial labour relations or with the benefits in the social insurance system or other central issues in fiscal policy (see Gyll et al. 1997).

Immediately after the election to Parliament 1998 and the EMU referendum 2003, the social democratic government invited the central trade union organizations and Svenskt Näringsliv, primarily represented by the large companies, to discuss economic growth. The origins of these "growth talks" between 1999 and 2004 were the complaints by the companies that the capital and wealth taxes and absentee rates among wage earners were too high. These meetings were cancelled in Spring 2004 as Svenskt Näringsliv concluded that the discussions had not been constructive. ${ }^{18}$ Thus, in the 1990 s and 2000s, there were no revival of the "Harpsund meetings" (Harpsund is the representation residence for the Swedish Prime Minister), the corporative arrangements in the 1950s and the 1960s that

\footnotetext{
${ }^{17}$ The Director General of Svenskt Näringsliv has recently expressed a negative attitude towards the fiscal rules (Bäckström 2011).

${ }^{18}$ See e.g. the interview with Jakob Wallenberg in Currents Magazine (2004).
} 
gave representatives of big business the opportunity to express their opinion about social democratic policies.

The weak impact of Svenskt Näringsliv and the large multinational companies on Swedish economic policy was largely the result of a "silent agreement". The companies and their representatives endorsed the termination of wage-earner funds, the deregulations of product and labour markets and the reduction of taxes on labour incomes and companies (by the 1990-1991 tax reform) and on capital incomes and wealth (by the centre-right governments in the early 1990s and in the 2000s). In the early 1990s, Sweden's corporate income tax rate was one of the lowest in the OECD. ${ }^{19}$ Furthermore, Swedish export companies benefitted from reductions in payroll taxes during the currency crisis in November 1992 and the weakening of the SEK under flexible exchange rates, especially during the first half of the 1990s. Finally, the success of Swedish export industries after the deep economic crisis in the early 1990s eased the pressure on Swedish governments to adjust economic policy to the interests of capital and the demands by the business sector for policy favours.

But such a silent agreement is not the whole explanation of the weaker influence by capital interests on economic policy in the 1990s and 2000s. Svenskt Näringsliv had initiated coordinated wage agreements in the mid-1950s. In the 1990s and 2000s, the organization aimed to abandon central wage agreements completely in favour of negotiations at the company level, but failed to do so. Furthermore, economic policy in

\footnotetext{
${ }^{19}$ OECD database, Corporate and Capital Income Taxes. In 2010, Sweden was in a group, together with the other Nordic countries, with medium profit taxes.
} 
the 1990s and 2000s was not fully in line with the general interests of capital or the interests of large multinational companies. In the previous decades, established industries and companies in the exposed sector had been patronized by beneficial tax rules, devaluations, grants to industries in crisis and regional subsidies (primarily benefiting the automobile companies in the 1980s). In contrast, the large Swedish companies were not unambiguously favoured by the 1990-1991 tax reform. The old profit tax system included ample room for tax allowances benefiting the large capital-intensive companies in particular. Furthermore, Svenskt Näringsliv and its member companies were not able, even under centre-right governments, to fully abandon the job security laws from the 1970s. Nor could they prevent the social democratic government from reintroducing wealth taxes and implement a specific tax on higher labour incomes (värnskatten) in the mid-1990s, and they were unable to persuade the centre-right government to abolish this tax in the 2000s. Moreover, Svenskt Näringsliv and the majority of the large companies did not succeed in making Sweden a member of the EMU. (Some managers and owners, particularly in raw materials industries, were opposed to Swedish EMU membership.) A referendum in 2003 clearly rejected a proposal of EMU membership that had the support of the social democratic leadership.

The political defeats of Svenskt Näringsliv in the 1990s and 2000s largely reflected that the organization and its leading companies were regarded by the governments as one among several other special interest groups. The social democratic government had a rather cool attitude to the demands by the large companies at the "growth talks" 19992004 and did not refrain from criticizing the generous severance pay and bonus programs 
for CEOs. During the years of "Harpsund democracy" the social democrats' view of big business had been less critical and more respectful. Even the non-socialist parties began to treat Svenskt Näringsliv and its influential large companies as special interest groups rather than as allies in the struggle against socialism. The centre-right government in the 2000s treated the claims by Svenskt Näringsliv (and the large multinational companies) as similar to LO claims. On several occasions during the financial crisis, the Minister of Finance Anders Borg criticized the business sector (especially the banks) for paying too high CEO bonuses. In turn, this popular criticism contributed to the marginalization of Svenskt Näringsliv and its leading companies in the Swedish economic-policy discourse. Svenskt Näringsliv's temporary return to Swedish corporatism in the early 2000s, when the organization participated in meetings about growth with the social democratic government, reflected a fear among the leaders that the organization had been reduced to a narrow interest group among many others. However, the marginalization of Svenskt Näringsliv was less obvious and dramatic than that of LO in the 1990s and 2000s.

New economic theories challenging corporatism contributed to the marginalization of labour but also of capital in the economic policy-making process. Modern macroeconomics recommends neutral expert decisions and departure from national planning, thereby excluding any participation of labour market organizations in the formation of economic policy. However, "voluntary" incomes policy survived the transformation into a new economic policy regime in Sweden and the other Nordic countries. 
The weaker link between capital interests and economic policy in the 1990s and 2000s is also connected to some political-institutional and economic-structural factors. The change to flexible exchange rates made it harder for Svenskt Näringsliv and its members to push for measures improving the global competitiveness of the Swedish companies. What is more, the industrial agreements had weakened the role of Svenskt Näringsliv, despite the fact that the organization was more successful than LO in coordinating the members bargaining strategies and in solving (or displacing) internal conflicts. The professionalism of economic policy was another challenge to the central labour-market organizations, including Svenskt Näringsliv, in the 1990s and 2000s (see next section). But the marginalization of Svenskt Näringsliv in economic policy making was reinforced by its own decision to abandon corporatism.

Svenskt Näringsliv refrained in the early 1990s from participation in almost all the public and semi-public arrangements (including the National Labour Market Board) that were essential parts of the Swedish corporative model. The organization felt that only LO would gain by corporatism. Participation in the growth talks with the social democratic government at the end of the 1990 s and the early 2000 s was most likely only a temporary departure from Svenskt Näringsliv's rejection of corporatism. The new Director General of Svenskt Näringsliv in 2005, Urban Bäckström (formerly the Governor of the Central Bank), openly declared that the era of meetings with the government was over. The organization's withdrawal from corporatist institutions in the 1990s and 2000s certainly implied (as the lack of any parallels to the Harpsund meetings) a weaker direct influence of employer interests on Swedish economic policy. 
Less intense contacts between the business sector and the governments in Sweden in the 1990s and 2000s is also explained by the strong increase in foreign ownership. Such ownership is much more common in Sweden than in the other Nordic countries. ${ }^{20}$ In fact, in the 1990s and 2000s, some of the large Swedish multinational companies were taken over by foreign companies, financial institutions and individuals. The largest companies in the pharmaceuticals and raw materials industries in Sweden are controlled today by foreign owners (by Anglo-American and Austrian or Finnish owners respectively). In fact, among the 20 largest exporters from Sweden in 2009-2010 (see Largest Companies, 2011) only eight were controlled by Swedish owners.

However, the argument that increasing foreign ownership in the 1990s and 2000s weakened the influence of capital interests on Swedish economic policy should not be exaggerated. With the exception for the automobile companies, SAAB and Volvo, and the producers of trucks and buses, the Volvo Group and Scania, the large multinational companies in engineering (and the two largest steel companies Sandvik and SSAB) are still in the hands of the Wallenberg group or Handelsbanken. Thus, even in the 1990s and 2000s, there were good opportunities for close contacts between leading politicians and representatives for the Swedish business sector. ${ }^{21}$ The reduced involvement of Svenskt

\footnotetext{
${ }^{20}$ There was a strong increase in the foreign companies' share of total employment in Sweden in the 1990s and 2000s. In the late 2000s, Sweden was in the group of OECD countries with the highest employment share for foreign-owned companies, while the other Nordic countries were in the group with the lowest share for these companies (Västsvenska Industri- och Handelskammaren 2008, Figure 1 and 2).

${ }^{21}$ Mainly through its investment company Investor, the Wallenberg family is still the dominating owner of Ericsson, ABB (an electrical company established trough a merger between the Wallenberg-controlled Swedish company ASEA and the Swiss company Brown Boveri in 1988), SKF, Electrolux, Atlas Copco and SAAB (producer of aeroplanes). Through its investment company Industrivärden, Handelsbanken is the largest owner of the two steel companies SSAB and Sandvik and the second largest owner of Ericsson
} 
Näringsliv and business interests generally in the policy-making process largely reflected a silent agreement (e.g. through a strong recovery for the export industries), a new strategy (away from corporatism), and, as in the LO case, the proliferation of new (anticorporatist) economic theories, the decentralization of wage bargaining and the professionalism of Swedish economic policy.

\section{The strategic role of professional economists}

The introduction of a new economic-policy regime in Sweden in the 1990s is hard to explain without reference to new economic doctrines. At the same time, the strong position of professional economists, especially high civil servants in the Ministry of Finance (some of them politically appointed), was a condition for the breakthrough of the new economic ideas. The group of influential professional economists also includes top officials in the Central Bank, primarily the six decision makers at the Executive Board elected for five or six years in accordance with the new legislation in the late 1990s. Furthermore economic experts at the National Institute of Economic Research (Konjunkturinstitutet), the commercial banks, and also in the OECD, IMF and World Bank belong to "an expert culture" of importance for the orientation of Swedish economic policy. These economists are not directly involved in the formation of economic policy, but their opinions and recommendations are often of crucial importance. At times, they appear to serve as direct guiding principles for the policy makers and their "core" experts.

and the Volvo Group. Handelsbanken is one of the four leading commercial banks in Sweden, while one of the other banks (SEB) is controlled by the Wallenberg family. 
There is evidence that the influence of professional economists on economic policy increased in Sweden during the 1980s, particularly at the expense of LO and ministries other than the Ministry of Finance. The 1980 Medium Term Survey, developed by the Ministry of Finance under a non-socialist government, was the first official document criticizing public sector growth and Keynesian domestic-demand management. The survey laid the ground for the reorientation of Swedish economic policy: measures to increase the cost competitiveness of Swedish companies would be given priority and the exposed sector would be stimulated at the expense of the public sector. However, already during the second half of the 1970s, there had been political concern for the profit crisis, loss of Swedish market shares and the emergence of a structural public deficit. This makes it hard to decide whether the retreat from Keynesian stimulation of domestic demand during the recession in the early 1980s was expert or political led.

The role of experts was more obvious during the social democratic government 19821991. The 1982 devaluation along the social democratic "Third Way" was not the only option. The structural public deficit (and current-account deficit) could have been met by restrictive fiscal policy alone. Ahead of the 1982 election there were also plans within the party to fight post-OPEC II unemployment by means of Keynesian domestic-demand stimuli (public infra-structural investments, housing programs, etc.). During this social democratic government, the efforts to enlarge the exposed sector through a strong devaluation of the SEK and predominantly restrictive (though countercyclical) fiscal policy were planned by a small number of economic experts with political agendas. The 
same experts recommended that the SEK be linked to the German Mark after the 1982 devaluation (Bergström 1987, 126-128, 193-201, Feldt 1991, 60, Elmbrant 1993, ch. 910, Lindvall 2004, 74-78). Furthermore, when the credit market was deregulated in 1985 these experts sanctioned (together with the Minister of Finance, Kjell-Olof Feldt) the decision. They even participated in the decision making process as representatives of the government in the Central Bank's General Council. The proposal had been worked out by a small number of top officials in the Central Bank. In the late 1980s, a group of experts within the Ministry of Finance, Kjell-Olof Feldt and the leaders of the Central Bank initiated the abolition of the currency controls (Elmbrant 1993, 126-127, Lindvall 2004, 78).

There was no debate between the political parties or within the social democratic government ahead of the decisions to regulate financial markets. The involved experts and politicians considered deregulation as too technical, urgent and inevitable for general political discourse. However, during the second half of the 1980s, strong tensions evolved between the Ministry of Finance and other ministries. The heads and experts of these ministries held that Kjell-Olof Feldt and his advisors were orchestrating a neoliberal attack against the Swedish model. Feldt and his experts on the other hand blamed especially the Department of Social Affairs (and LO) for having obstructed necessary steps to cut public transfers and fight overheating. The absence of such conflicts within the social democratic governments in the 1990s and 2000s indicated that the Ministry of Finance had finally won the day. 
But the influence of experts on Swedish economic policy did not become unambiguously stronger in the 1990s and 2000s. It was not even obvious in this period that the changes in economic policy were driven by experts rather than by politicians. First, tensions within the centre-right government 1991-1994 actually reduced the power of the Ministry of Finance. In this period strategic decisions on economic policy were made at ministerial meetings or in the Prime Minister's Office. Second, the Ministry of Finance regained its former position once the new social democratic government took office, but in that government, the flamboyant Minister of Finance Göran Persson had a strong influence on Swedish economic policy independently of the ministry's top civil servants. In fact, the real power of the Minister of Finance declined when Persson became Prime Minister in 1996. For example, Erik Åsbrink, who had succeeded Persson as a Minister of Finance, resigned in 1999 following a conflict with Persson.

Third, it is difficult to assess whether economic policy was expert led or political led in the 1990s and 2000s because of an initially strong consensus between the political parties and also between the economic experts and politicians. This consensus was a result of the traumatic national experience of a deep recession and public budget crisis in the early 1990s and of the gradual convergence in economic thinking and views of economic policy in the 1970s and 1980s. In the 1980s, a small group of experts inspired by new macroeconomic ideas had pioneered a new approach to Swedish economic policy, an approach that was first generally accepted by social democratic and non-socialist politicians in the 1990s. 
The strong 1990s consensus among politicians and their economic experts was particularly conspicuous in the case of the restrictive fiscal policy and the introduction of fiscal rules. In addition, the independent role of Göran Persson refutes the hypothesis that the underlying consensus ultimately reflected the opinion of professional economists. When arguing in the mid-1990s for a very restrictive fiscal policy Persson did not refer to the importance of reducing inflation expectations in accordance with the new consensus in macroeconomics. He merely argued for fiscal austerity from a cameralist (book accounting) viewpoint. Already as a Minister of Finance, Persson distanced himself more clearly from economists than both his followers and his predecessor Feldt. ${ }^{22}$ In Persson's cameralist perspective the emergence of a large public deficit and public debt was a sufficiently strong argument per se to conduct a very restrictive fiscal policy in the mid1990. Persson was even prepared to ignore recommendations by academic economists who suggested that most of the restrictive fiscal measures might be postponed until the crisis was over (SOU 1993:16, 188). Moreover, economic experts in the Ministry of Finance later declared that they had preferred a somewhat less restrictive fiscal policy than Persson. It seems also that Persson was the initiator of the fiscal rules although these were developed in close contact with his successor as a Minister of Finance (Åsbrink) and top officials in the Ministry of Finance who also participated in working out the details. $^{23}$

\footnotetext{
${ }^{22}$ Persson's view of the public budget crisis in Sweden during the 1990s is clearly represented by his device "Those who are in debt are not free" which was also the title of his book about the budget consolidation (Persson 1997). Persson's book-accounting view of fiscal policy was in fact similar to that of Gunnar Sträng, the social democratic Minister of Finance from 1957 to 1976.

${ }^{23}$ Interview 14 July 2011 with Ingemar Hansson, the head of the Economic Department at the Ministry of Finance 1992-1999.
} 
With these caveats, we are inclined to conclude that experts increased their power over Swedish economic policy, and that they were also the main actors behind the changes in economic policy in the 1990s and 2000s. However, when analyzing the forces behind deregulation and central-bank autonomy, it is necessary to include some influential academic economists in the group of economic experts.

First and foremost, the professionalism of Swedish economic policy was largely institutionalized in the 1990s. The most striking example is the development of an independent central bank. Monetary policy is determined today by the six experts on the bank's Executive Board. According to the central bank reform 1998-1999 the General Board, formally appointed by Parliament, no longer has any direct control over Swedish monetary policy. Moreover, the position of the Ministry of Finance was strengthened by a budget reform in 1996. The commission that recommended the reform (in 1993) considered Sweden's budget institutions as the second worst among 13 Western European countries in the early 1990s. Only Italy was worse. The budget reform transformed these institutions - Sweden now has a top-down public budget process where aggregate decisions in Parliament on the central government budget are made prior to the decisions on the individual parts (Wehner 2007).

Second, the claim that changes in economic policy-making during the latest decades have been policy led is weakened by the fact that the politicians accepted the development towards (more) central-bank independence and restrictions on fiscal policy. These reforms have certainly reduced their influence on economic policy. Such voluntary 
surrender of sovereignty by the political parties is hardly in accordance with those political economy theories that were fundamental for the policy reforms under review. ${ }^{24}$ Third, the decision in November 1992 to abandon fixed exchange rates and in January 1993 to define a 2 per cent inflation target was made by a small group of top officials in the Central Bank together with politicians on the bank's General Council. Their mandate was from Parliament rather than from the government. ${ }^{25}$

Fourth, as experts in public committees, leading academic economists subscribing to new theories of rational expectations and selfish or myopic political behavior worked out the proposals for an independent central bank guided by an inflation target (see SOU 1993: 20, appendix 2). Furthermore, due to the strong consensus between the social democrats and the non-socialist parties as well as between politicians and economists, experts had ample opportunity to make independent proposals in public committees on deregulation of product markets and changes in the tax system (1990-1991). For example, a small group of academic economists (and the Director General of Konjunkturinstitutet) were central actors when the Swedish energy market was deregulated in the mid-1990s (Högselius and Kaijser 2007, 79). Furthermore, as members of the Executive Board academic economists have a strong influence on the practical execution of the Central Bank’s monetary policy.

\footnotetext{
${ }^{24}$ The political decisions that introduced restrictive fiscal rules and independent monetary institutions are more in line with the psychological theories about self-disciplinary measures at hyperbolic discounting (see Erixon 2009).

${ }^{25}$ At that time Erik Åsbrink was the social democratic chairman of the General Council within the Central Bank. Åsbrink was also one of the initiators of the social democratic economic policy (including the deregulation of the financial market and the tax reform) in the 1980 and the early 1990 s.
} 
The use of leading economists as experts in public and parliamentary committees and as governmental advisors was not a new phenomenon in Sweden (see Lönnroth 2010). On the contrary, it had been typical for the country since the early $20^{\text {th }}$ century. But it seems that the power of economic experts was reinforced in the 1990s by the strong consensus among (leading) Swedish economists about new economic policy and the theory underpinning it. Had there been more diverging opinions in the economic profession about e.g. central bank independence, inflation targets and the need for a restrictive fiscal policy in the mid-1990s, this might have resulted in a more differentiated view on economic policy among representatives of the political parties and the central labourmarket organizations. The absence of an economic-policy discourse among academic economists in the 1990s and 2000s is also explained by their march back to the institutions, a general phenomenon in economics during the latest decades. More emphasis on publications in scientific journals has reduced the incentives of academic economists to participate in public committees and the economic-policy debate.

A fifth argument in favour of the hypothesis of expert-led economic policy in Sweden in the 1990s and 2000s is the exceptionally strong position of the Ministry of Finance (and its budget department) and Anders Borg under the present centre-right government. The position of the Ministry and its head was strengthened by the apparent macroeconomic success of Sweden. Borg's exceptional position in the government is based on his status as a mainstream economist rather than as a representative for the largest party in the coalition. Foreign experts' appreciation of Swedish economic policy made it easier for 
Borg to meet the criticism from other ministries (especially of the changes in the social insurance system) and also from academic economists. ${ }^{26}$

In sum, there was next to no political debate on the introduction of a new economicpolicy regime in the 1990s. There was a profound consensus about necessary changes, not only between the political parties but also between the politicians and their economic experts. Accordingly, it is difficult to disentangle whether the transformation of the policy regime was led by experts or by politicians. We lean, however, towards the conclusion that Swedish economic policy was generally formed by economic experts in the 1990s and 2000s. This is particularly so if we extend this group of experts to include the Ministers of Finance who have been strongly wedded to their experts. We also maintain that some strategic changes in Swedish economic policy, mainly the deregulation of the product markets, the change to flexible exchange rates, the introduction of an explicit inflation target and the development (and content) of the proposal of central-bank independence, were expert led. This is particularly so if we include some leading academic economists (governed by the new economic ideas) in the group of experts.

\section{EU adjustment}

In November 1994, an advisory referendum approved Swedish membership in the EU by 52 per cent of the vote. When joining the union in January 1995 Sweden also ratified the

\footnotetext{
${ }^{26}$ Academic economists criticized the fiscal policy by the non-socialist government for focusing too much on tax cuts and for having been too cautious during the Great Recession (Swedish Fiscal Policy Council 2011, 65-66, 235).
} 
Maastricht Treaty from November 1991. Thus Sweden was formally obliged to later become a member of the EMU (the Economic and Monetary Union) and also to follow the convergence rules of low inflation, low interest rates, stable exchange rates and public budget deficits not exceeding 3 per cent of GDP and government debts not growing larger than 60 per cent of GDP. But Sweden's adjustment to the EU had already started in the early 1990s through the EEA (the European Economic Area) Agreement, that entered into force in January 1994. The agreement implied that the countries should follow the Single European Act (signed in 1986) stipulating free movement in goods, capital, labour and services in the European Community from 31 December 1992. Already when they submitted the membership application in 1991, Swedish governments felt impelled to start adjustment in anticipation of membership. The centre-right government 1991-1994 reduced VAT taxes to fit the tax profile of the EU countries. The government also argued, as the following social democratic government, in favour of contractionary fiscal policy measures with reference to the Maastricht convergence rules.

It cannot be denied that EU adjustment was an important determinant of Sweden's change of economic policy regime in the 1990s. It seems that the early 1990s deregulation wave was heavily influenced by the demands for EU convergence, especially the provisions in the Single European Act and the EU rules against restrictions on competition (see Lundqvist 2003). Yet, we shall maintain that the EU adjustment argument is less valid than our other arguments (the deep recession and financial crisis in the early 1990s, the negative experience of economic policy in the past, the growing power of experts, primarily at the expense of LO, and the new economic ideas). Swedish 
politicians and top officials used the EU integration argument in order to legitimate a change in economic policy (including a restrictive fiscal policy) that they considered as inevitable against the background of new theories, the public budget crisis and the negative experiences of economic policy in the 1970s and 1980s. Our claim that EU convergence was less salient for the new economic-policy regime is supported by the fact that also countries outside Western Europe deregulated and conducted an economic policy along the lines of the Maastricht convergence rules. What is more, the change to flexible exchange rates in Sweden challenged the principle of stable exchange rates in the Maastricht Treaty. The plans to return to fixed exchange rates (the ERM) was soon abandoned when it became clear that Sweden performed satisfactory under flexible exchange rates.

Sweden's budget consolidation, fiscal rules and apparently good macroeconomic performance explains why the Stability and Growth Pact (SGP) was marginal to the economic-policy debate and also to the fiscal-policy decision process in the late 1990s and the 2000s (see Ministry of Finance 1999). The Pact from 1997 (in force from July 1998), institutionalizing the fiscal guidelines of the EMU convergence program, would commit all future EU members. The Pact's impact was further weakened by Sweden's rejection of EMU membership in the referendum in 2003. Sweden's fiscal rules were in fact stricter than the Stability and Growth Pact in one respect - the Swedish rule required a public saving surplus over the business cycle. This was only a recommendation in the SGP. 
In the 2000s, the EU commission regarded Sweden as an example to follow rather than as a country that had to converge to the union rules. The commission praised the mid-1990s restrictive fiscal policy. In the Lisbon strategy (2000) aimed at catching up with the United States in terms of GDP per capita levels, the commission and its experts saw Sweden (and also other Nordic countries) as a good example for other EU countries (Aghion et al. 2003). The commission emphasized Sweden's macroeconomic stability, all-embracing educational system, high R\&D expenditure, and flexible labour and product markets. The EU also recommended Sweden's ALMP programs for other member countries, but referred even more to the Danish flexicurity model than to the Swedish one.

While it seemed like a rule that other EU countries should adjust to Sweden, there was at least one exception. A verdict by the European Court in December 2007 declared that the blockade by the Swedish Construction Union of a Latvian company in the winter of 2004-2005 violated the EU principle of free mobility of services. The Latvian company Laval had won a contract for a school reconstruction in a Swedish municipality (Vaxholm) by paying Latvian (collective) wages instead of minimum wages for construction workers according to Swedish central agreements. The blue-collar trade unions in Sweden, and also in Denmark, feared that the Laval verdict would lead to wage dumping. In fact, leading politicians in the current centre-right coalition had expressed related fears that the verdict could be a threat to the Swedish model. According to EU, temporary posted workers in other countries must be paid legislated minimum wages. 
However, legislation on minimum wages in Sweden would be in conflict with the Saltsjöbaden Agreement.

\section{SWEDEN IN THE YEARS OF THE GREAT MODERATION}

The macroeconomic performance of Sweden 1998-2007

The question is whether Sweden's macroeconomic performance in the 1990s and 2000s is explained by the new economic-policy regime or by external and structural factors beyond the control of domestic decision makers. We find that by 1998, all the components of the new macroeconomic policy had been put in place, serving as a set of economic-policy routines. 1998 was also the year when the budget consolidation and the regulation wave (on the product market) were completed. We shall consider 2007 as the end year of the routine period. Since then, the new regime was tested under exceptional conditions and also combined with some extraordinary measures.

1998-2007 was a period of low economic volatility in the EU and OECD countries. Although an era of "Great Moderation" (cf. Stock and Watson 2002) the period was not free from negative macroeconomic surprises. In the early 2000s, an international recession coincided with an ICT crash that hurt Sweden, given her specialization in ICT products. The Swedish ICT flag ship, Ericsson, was on the brink of bankruptcy in 2001. The company survived first after a reconstruction, in which its mobile-phone division 
was merged with that of the Japanese electronics company Sony. Yet, like in other OECD countries, the early 2000s recession in Sweden was mild and short-lived even if the employment recovery was delayed (see the references to jobless growth). The smooth economic development in the OECD and EU areas in 1998-2007 was mainly due to unsynchronized business cycles in major countries (even within the Euro area) and the absence of large oil shocks (although oil prices were increasing). Furthermore, in the 1998-2007 period, OECD inflation was low in the OECD also in comparison with the previous years in the 1990s (see Table 2* in Appendix 2). Lower inflation in many OECD countries mainly reflected high productivity growth and more imports from lowcost countries. Moreover, despite the backlash in the early 2000s, OECD unemployment was generally lower in the $1998-2007$ period than in the early 1990s. It was also decreasing at the end of the period. Finally, GDP growth was higher in the OECD countries (including the Euro countries) from 1998 to 2007 than earlier in the 1990s (with Germany as a major exception).

Even with favourable external conditions for the new economic policy regime, e.g. the absence of strong international demand and supply shocks, it cannot be excluded that Sweden performed better than other countries in the period under review. Not surprisingly, business cycle fluctuations (the standard deviation of the output gap) was larger in small open countries like Sweden than in the large Euro countries (and the United Kingdom) from the mid-1990s to the mid-2000s. However, in the 1998-2007 period, the volatility of the economy seems to have been larger in Sweden than in the other Nordic countries (especially Denmark) and also larger than in small open Western 
European countries on average (own estimates based on OECD 2011, Table 10, see also Cotis and Coppel 2005, Table 4). The latter group includes here the Nordic countries as well as Austria, Belgium, the Netherlands and Switzerland. But Sweden had lower inflation (CPI) in the 1998-2007 period than the OECD and Euro countries on average, than the other Nordic countries and also than the other small open Western European countries on average. The average annual rate of inflation in Sweden, 1.2 per cent, was significantly below the rate for the group of small Western European countries (1.7 percent). Among these countries only Switzerland had lower inflation than Sweden in the 1998-2007 period. Sweden's relative inflation was particularly low in the (1997)19982000 and 2004-2006 periods.

On the other hand, in the 1998-2007 period, the rate of unemployment in Sweden was the same as in total OECD (the average annual rate was 6.7 per cent) and in fact higher than in other Nordic countries, except Finland (see Table 1* in Appendix 2). Swedish unemployment was also higher than unemployment in the small open Western economies on average (5.4 per cent), and, for example, than in the United States ( 4.9 per cent). And at the end of the period under review the Finnish unemployment rate moved close to the Swedish rate. These comparisons are based on the standardized ILO measure used by the OECD and also by Swedish authorities since 2007. The measure classifies full-time students who are job seekers as unemployed, an inclusion that is probably unfavourable for Sweden. In any case, it is striking that Sweden, even after the crisis in the 1990s, no longer belonged to the group of OECD countries with the lowest rate of unemployment. Furthermore, in the 1998-2007 period, Sweden failed to return to the high labour force 
participation rates of the early 1990s. The rate began to increase again in 2005, but from 1990 to 2006, no other OECD country with the exception of Turkey and Poland experienced a similar fall in the labour force participation rate (OECD 2005a and 2010, Table B). The strong increase in long-term sickness absence (more than two months) in 1998-2002, especially among women, made a significant contribution to the decline in the Swedish labour force rate.

The ambiguous stabilization-policy outcomes in Sweden in the 1998-2007 period justify a comparison between Sweden and other countries in terms of the Phillips curve, that is, the trade off between inflation and unemployment. The Phillips-curve comparisons below (Figures 1-3), are based on CPI, the ILO measure of standardized unemployment, and on an equal weighting of unemployment and inflation (annual data). Sweden had a better Phillips curve than the EMU countries on average (Figure 1) and also than Finland in the 1998-2007 period. The country had a similar (negatively sloped) Phillip curve as the other Nordic countries less Finland and the small countries on the European continent. But it is striking that Sweden climbed down the Phillips curve to a larger extent than the other Nordic countries in the 1998-2007 period if Finland is excluded. Sweden's move downward along a similar Phillips curve is also obvious in comparison with the small open Western European countries less Finland on average and with the United States (see Figures 2 and 3). 
Figure 1: The trade off between inflation and unemployment, Sweden and the EMU countries, 1998-2007

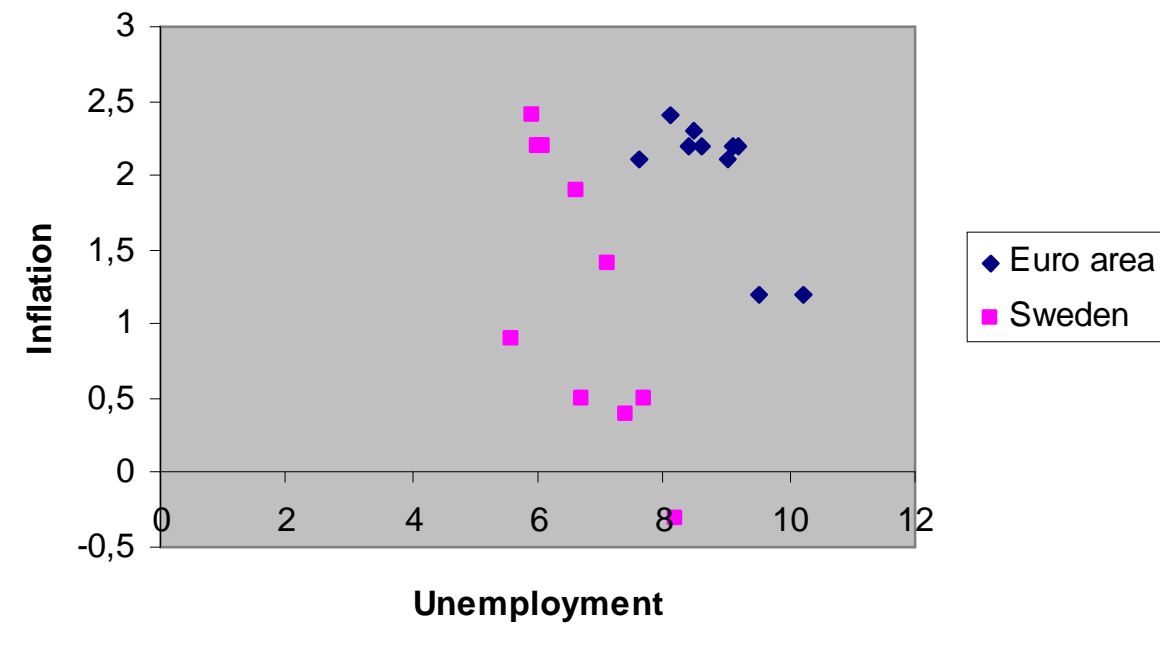

Source: OECD 2005b and 2011.

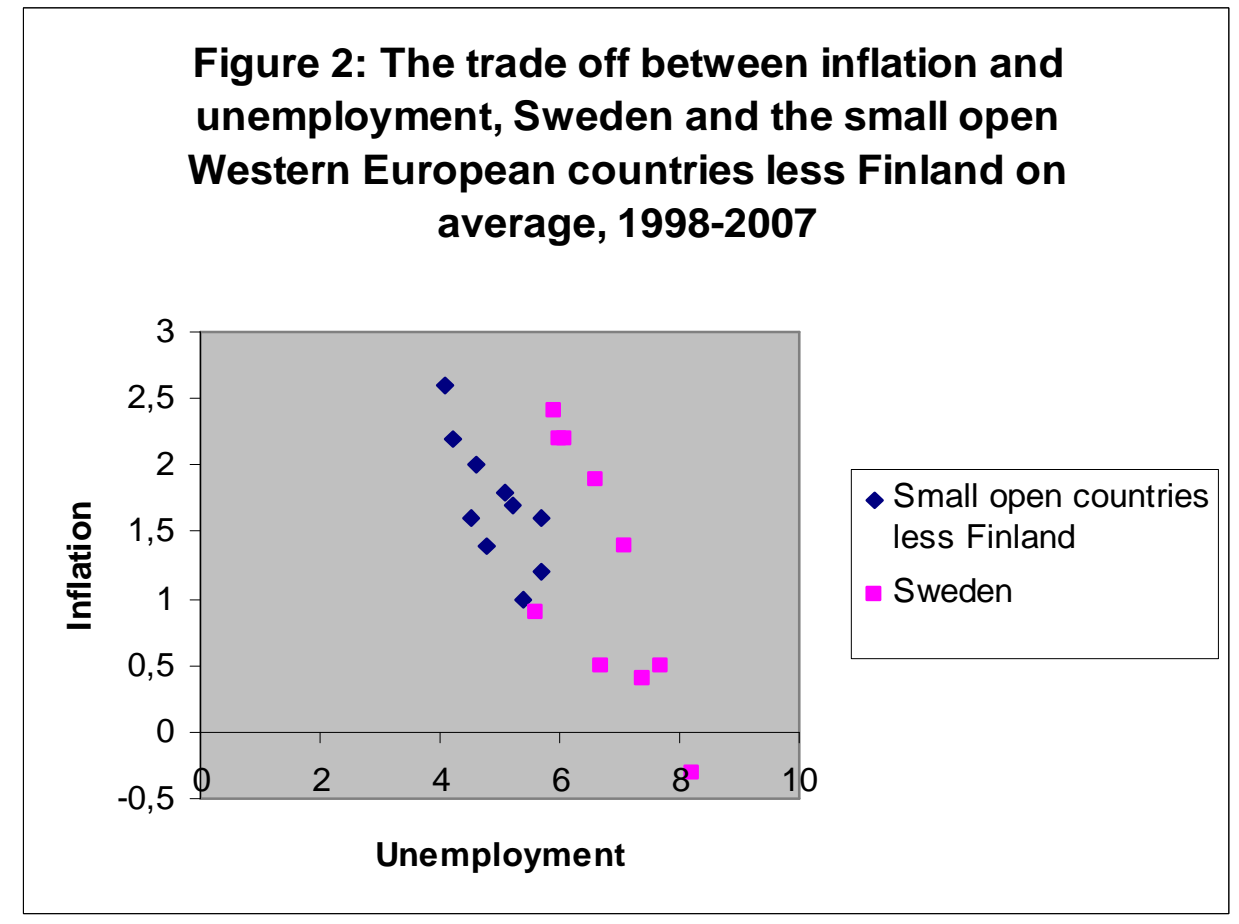

Source: OECD 2005b and 2011. 


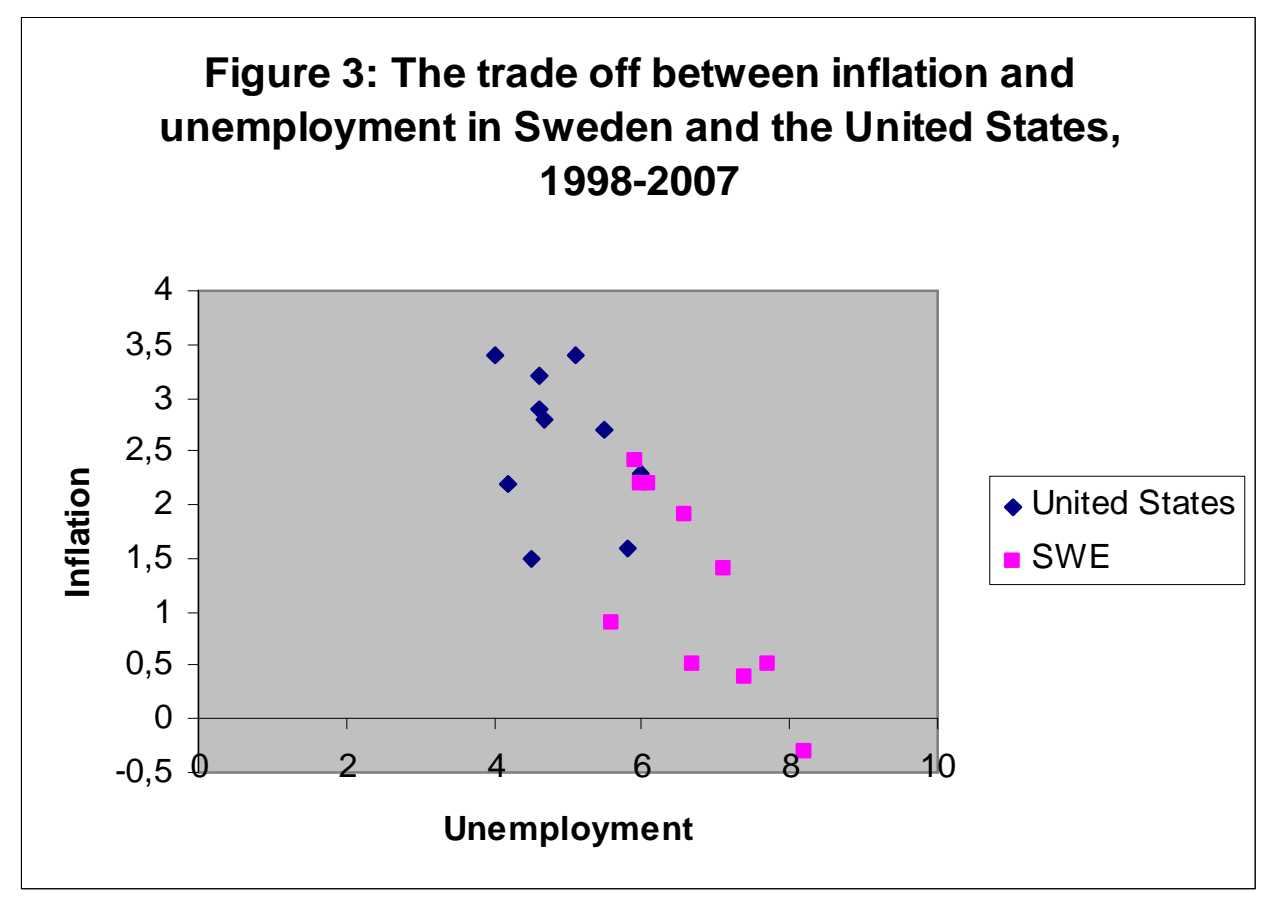

Source: OECD 2005b and 2011.

Sweden's macroeconomic performance in 1998-2007 improves if we also take account of the growth rate. Swedish GDP growth was 3.4 per cent per year on average (OECD 2011, Table 1). Among the small open Western European countries only Finland had a higher growth rate (3.7 per cent). For example, Sweden had higher GDP growth than the United States ( 3.0 per cent) and than the EMU countries on average ( 2.3 per cent). It must be noted, however, that comparisons based on GDP data from the mid-1990s and onwards give a favourable impression of Sweden and Finland. During the first half of the 1990s annual GDP growth (on average) in Sweden and Finland was among the lowest in the OECD area and even negative.

In the 1995-2006 period Sweden experienced a "productivity miracle". Among the OECD countries only South Korea and Ireland had higher (labour) productivity growth 
than Sweden's total economy although Finland was rather close behind (see Table $3 *$ in Appendix 2). Sweden's growth in labour productivity (average annual growth in GDP per hour) was 2.6 per cent. The similar growth rate in the small open Western European countries on average (Ireland is excluded from this group) was 1.7 per cent and in the EMU countries on average 1.1 per cent. In such growth comparisons, Sweden may be at a disadvantage due to her large public sector. The productivity performance of Sweden from the mid-1990s to the mid-2000s was even more impressing in the business sector and especially in manufacturing. Furthermore, like Finland, Sweden experienced high labour productivity growth also during the first half of the 1990s. By combining high productivity growth with low GDP growth Sweden and Finland were outliers in the OECD area during this period.

Thus, in the 1998-2007 period, Sweden was no longer the country of low unemployment and economic growth but rather the country of low inflation and high (productivity) growth in an international perspective. The macroeconomic performance of Sweden in the period with a new economic-policy regime was completely opposite to that in the 1970s and 1980s.

Was Swedish macroeconomic development caused by the new economic-policy routine?

Relatively low inflation in Sweden in the 1998-2007 period is seemingly due to structural factors common to small open Western European countries, but also to the effects of a restrictive monetary policy. Like in other OECD countries that gave priority to price 
stability Swedish monetary policy was countercyclical by a "divine coincidence" in the 1998-2007 period. Thus inflation pressure was alleviated in the recessions and aggravated in the recoveries (cf. Blanchard and Gali 2007, 44). But in the 1998-2007 period, Sweden had more low-inflation points than the EMU countries (on average) on their respective Phillips curves (Figure 1). And Sweden moved downwards along a similar Phillips curve to a larger degree than other European countries and also than major OECD countries outside Europe (Figures 2 and 3). By international standards, the Swedish Central Bank pursued a restrictive monetary policy in 1998-2007. First, the explicit inflation target made the struggle against inflation more ambitious in Sweden than in e.g. the United States. Second, the Swedish Central Bank pursued a rigorous monetary policy given its inflation target. With the exception of 2001-2002 and 2007 the Central Bank consistently undershot the 2 per cent target (with various inflation measures). In 1998-2000 and 20042005 Swedish inflation even fell below the target's lower limit of 1 per cent (see Giavazzi and Mishkin 2006, OECD 2011, Table 18).

Fiscal policy was also countercyclical in Sweden in the 1998-2007 period, with the possible exception for the election year 2006. The social democrats ran an expansionary fiscal policy before the 2002 election. But this policy was legitimized on Keynesian grounds, as 2002 was a recession year. ${ }^{27}$ Swedish fiscal policy was predominantly restrictive in the 1998-2007 period, accumulating a public budget surplus in line with the fiscal rules of the new economic-policy regime.

\footnotetext{
${ }^{27}$ There were also tendencies towards a procyclical fiscal policy in 1999, reflecting political business-cycle behaviour (see the election in September 1998) and Prime Minister Persson's cameral approach to fiscal policy.
} 
But fiscal policy was more restrictive on average in e.g. Denmark, Finland, Belgium and Switzerland than in Sweden in the 1998-2007 period. ${ }^{28}$ There is no general evidence that fiscal rules (including the Stability and Growth Pact) were decisive for fiscal consolidation in the OECD countries in the 1998-2007 period. And, as already mentioned, fiscal rules seemed to have been endogenous, thus adopted by countries with a strong fiscal discipline. But more importantly, the contractionary fiscal policy in other countries is evidence that fiscal policy was not responsible for Sweden's more accentuated slide down the Phillips curve compared to other small open Western European countries. Monetary policy was more salient than fiscal policy for the relatively low inflation in Sweden in the 1998-2007 period.

Accordingly, monetary restraint was also a pivotal cause of Sweden's high unemployment in an international perspective in the 1998-2007 period. Together with fiscal austerity, monetary policy also contributed to historically high unemployment in Sweden. But high Swedish unemployment from the mid-1990s to the mid-2000s was probably also due to asymmetric shocks in the labour market. Large immigration to Sweden resulted in higher unemployment given the wage structure, the flexibility of the labour market and the prevalence of discrimination and language difficulties. It also seems that the deep recession and the restrictive economic policy of the 1991-1997 period had long-run effects on unemployment, particularly through hysteresis effects (Erixon 2008). In neo-Keynesian terms, Swedish economists emphasized that the negative demand shocks during the first half of the 1990s had long-run effect on Swedish

\footnotetext{
${ }^{28}$ Estimates based on OECD 2011, Table 28. Fiscal policy was, however, less restrictive in Austria and the Netherlands than in Sweden in the 1998-2007 period.
} 
unemployment; job security and high unemployment benefits led to wage rigidities, despite the reforms of the 1990s (Holmlund 2009, 119).

The fact that monetary policy, and also fiscal policy in many cases, was more restrictive in Sweden than in other OECD countries suggests that we must look for other explanations of the country's relatively high GDP growth 1998-2007. Swedish GDP growth was mainly (net) export driven. This was related to foreign recoveries, the revival of the Swedish basic industries (producers of raw materials and investment goods) because of the East Asian (mainly Chinese) growth miracle and the weaker SEK 19962001 (especially against the dollar). Sweden's large surplus in the current account (and dramatic increase in the export share of GDP) in 1998-2007 supports the hypothesis that Swedish growth was export led, and that industries with low import propensities, mainly raw materials producers, functioned as a growth engine. ${ }^{29}$ Sweden's export and GDP recovery was also driven, disregarding the early 2000s, by the ICT sector, especially telecommunications (see below). Thus, explaining the relatively high production growth in Sweden 1998-2007, our emphasis must be on industry-structural factors or more precisely, on the simultaneous success of the traditional export industries and the ICT industries. Moreover the ICT sector explains the major share of the Swedish productivity miracle, and it was also an important determinant of the low inflation in Sweden in the 1998-2007. It remains to scrutinize the central role of the telecom industries in the Swedish economy, as well as the importance of the deregulations in the first half of the 1990s for the Swedish ICT wonder.

\footnotetext{
${ }^{29}$ The National Institute of Economic Research has associated the weakening of the SEK and the Swedish current-account surplus since the mid-1990s with a higher domestic saving propensity, partly for demographic reasons (National Institute of Economic Research 2011, 73-76).
} 


\section{The decisive role of the ICT sector}

The Swedish postwar accumulation model can no longer be associated with a hegemonic position for labour and the social democratic party (cf. Erixon 1997). Moreover, defining the Swedish growth engine in the 1990s and 2000s, we must emphasize the ICT sector and especially the telecom industries (including both products and services). In fact, the contribution by telecom industries to the (high) labour productivity growth in the Swedish business sector 1993-2005 was 30 per cent (Lundgren et al. 2007, 26-30). Teleproducts accounted for approximately $2 / 3$ of labour productivity growth in Swedish manufacturing in the 1991-2001 period. This contribution follows from telecom industry's larger share of employment in Swedish manufacturing and productivity increases within the industry itself (Lind 2003). The ICT sector also contributed to labour productivity growth in other sectors through the substitution of ICT inputs for labour (reflecting the rapid price decreases for ICT products) and the spread of ICT knowledge (leading to higher total factor productivity in sectors outside the ICT industries as well). All OECD countries with a specialization in ICT products and services experienced (with the possible exception for the United Kingdom) high productivity growth from the mid1990s to the mid-2000s. On the other hand, high productivity growth in Sweden and Finland during the first half of the 1990s reflected enforced rationalization and creative destruction, thus the elimination of low-productivity plants and firms during the deep recession. Analogously, the Swedish productivity miracle from the mid-1990s was the 
result of strong transformation pressure that is, fierce competition in high-tech industries, but also of positive driving forces, mainly extensive technological opportunities in these industries. $^{30}$

The Swedish tele-product sector is dominated by the multinational company Ericsson (founded in 1876). The company functioned as an organizational and technological hub both within the ICT sector and between the new and traditional industries in Sweden. In the early postwar period, Ericsson had, like the other large Swedish multinational companies, a strategic position in the Swedish economy, above all as a transmitter of foreign knowledge. Throughout the ICT revolution, Ericsson's role as a transmitter and also producer of new knowledge became even more important in the Swedish economy. The company's development of digital mobile telephones and communication systems in the first half of the 1990s showed that even though it was on the technological path of an established producer of tele-products, Ericsson was able to join the ICT revolution. Furthermore, from the mid-1990s to the mid-2000s, there was a rapid and extensive diffusion of new knowledge from Ericsson and its networks (including suppliers) as well as its spin-offs to other sectors of the Swedish economy. Given Ericsson's status as a producer of high technology products and transmitter of new knowledge in the 1990s and 2000s, it is no longer easy to distinguish a leading group of "mature" industries and companies in Sweden with strong ties to domestic and the international capital markets,

\footnotetext{
${ }^{30}$ It should be noted in addition that the economic crisis in the early 1990 s fostered a strong transformation pressure in general in the Swedish business sector. The disciplinary effect of (higher) unemployment (see Karl Marx) is another plausible explanation for Sweden's remarkable productivity performance from the early 1990s to the mid-2000s.
} 
and thus with negative effects on the development of new firms in dynamic markets (cf. Erixon 1997).

From the mid-1990s to the mid-2000, the ICT sector and Ericsson in particular made a significant contribution not only to Sweden's productivity growth but also, notwithstanding the sector's high imports, to the country's export-led economic development. Ericsson's share of Swedish export increased steadily during the second half of the 1990s. In year 2000, this share was almost 20 per cent in current prices (see Table 1 below). Ericsson's share of Swedish exports was even larger in constant prices reflecting the dramatic reduction in relative prices for ICT products. At the same time, the share of tele-products in Swedish export increased to 17 per cent in 2000. Ericsson's share of Swedish exports decreased during the ICT crisis in the early 2000s. In the 20032010 period the company's share of Swedish exports was stabilized around 9 per cent. But Ericsson is still the largest export company in Sweden.

Table 1. Export sales by Ericsson and the tele-product industry as a percentage share of total Swedish export, current prices, 1998-2010.

Ericsson/total Swedish export

\begin{tabular}{|l|l|l|l|l|l|l|l|l|l|l|l|l|}
\hline 1998 & 1999 & 2000 & 2001 & 2002 & 2003 & 2004 & 2005 & 2006 & 2007 & 2008 & 2009 & 2010 \\
\hline 16.3 & 18.7 & 19.7 & 15.0 & 10.8 & 8.8 & 9.6 & 9.6 & 9.1 & 9.0 & 9.2 & 9.5 & 8.8 \\
\hline
\end{tabular}

Tele-products/total Swedish export

\begin{tabular}{|l|l|l|l|l|l|l|l|l|l|l|l|l|}
\hline 1998 & 1999 & 2000 & 2001 & 2002 & 2003 & 2004 & 2005 & 2006 & 2007 & 2008 & 2009 & 2010 \\
\hline 13.8 & 15.9 & 17.0 & 11.8 & 10.1 & 8.9 & 9.9 & 10.0 & 8.9 & 7.3 & 7.3 & 7.3 & 8.6 \\
\hline
\end{tabular}

Source: Statistics Sweden and Ericsson annual reports. 
The extremely low inflation in Sweden in the 1998-2007 period is to a large extent a result of the Central Bank's inflation target and its overambitious - relative to the target fight against inflation. But the telecom industries also contributed to Sweden's low rate of inflation. First, unexpectedly strong productivity increases emanated from the telecom sector. This is a major explanation of the Central Bank's restrictive monetary policy in the 1998-2007 period, given its inflation target. Since the Central Bank underestimated the productivity shocks from the ICT sector, it also overestimated the risk of inflation (see Hüfner 2007, 11-12). In the 1995-2006 period, a positive relationship existed (with an information delay) between the ICT-led productivity increases and the deviations from the inflation target. Second, low wage increases in Sweden relative to productivity 19982007 was basically a result of the combined effects of strong productivity increases (through new technological opportunities) and price competition in the ICT sector. The reduction in prices for tele-products on the world market worsened the terms-of-trade for countries specialized, like Sweden, in these products. Figure 4 shows Sweden's terms-oftrade with and without tele-products 1990-2009. The Swedish terms-of-trade deteriorated from the mid-1990s, but not if tele-products are excluded. Worsening terms-of-trade conditions have a dampening effect on firms' profitability, thus reducing the room for wage increases. Negative terms-of-trade effects contributed (together with the weakening of the dollar from 2001) to the absence of a positive trend in profitability in Swedish manufacturing in the 1998-2007 period, despite the fact that this was mainly a recovery period (cf. Industrins Ekonomiska Råd 2011, diagram 4.6). 
Figure 4. Sweden's terms-of-trade, including and excluding teleproducts, 1990-2009. $1990=100$.

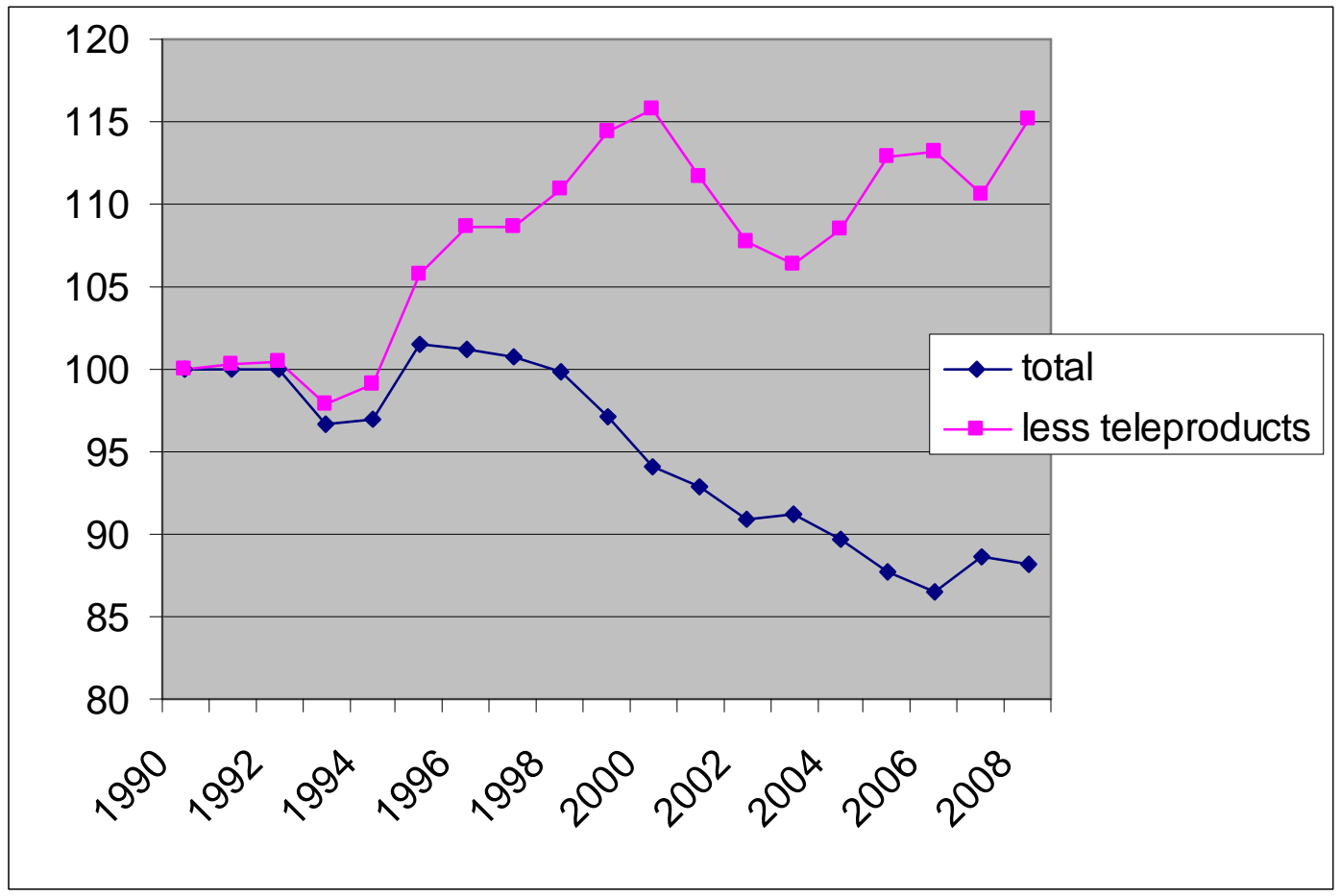

Source: Statistics Sweden and own estimates.

International comparisons have shown that wage restraint, measured as the wage lag relative to productivity increases, increased more in Sweden than in other EU countries with the exception for Finland from 1991-1998 to 1999-2004 (Hüfner 2007, 11). Many economists refer to the successful outcome of the incomes-policy arrangements in the new economic-policy regime, primarily the Industrial Agreement. The possibility of wage moderation through successful Swedish incomes policy cannot be fully excluded (though the pace of overall wage increases was primarily endogenously determined by changes in labour-demand conditions in the period under review). But the hypothesis that Swedish wage restraint is explained by the country's specialization in tele-products is 
supported by the developments in terms-of-trade and manufacturing profitability, as well as by the fact that also Finland, notwithstanding the differences in the wage negotiation system (see Vartiainen 2011), displayed a wage lag behind productivity similar to the Swedish one.

Increasing production and use of ICT products is also decisive for increasing earnings dispersion in Sweden from the mid-1990s to the mid-2000s. In the 1998-2007 period, increasing wage differentials in Sweden and other countries specialized in ICT products (for example Finland, United Kingdom, South Korea and the United States) reflected wage increases in the higher income brackets that is, for skilled labour (cf. Gustavsson 2007, Erixon 2008).

But it would be possible to argue that deregulation was responsible for Sweden's relatively low inflation, favourable Phillips curve (in comparison to the EMU countries) and the Swedish productivity miracle. Deregulation might have led to high productivity growth in Sweden by increasing the competitive pressure in the ICT sector, the size of this sector and the capacities of other industries to adopt the new technologies. But it is equally plausible that the ICT-led productivity boom in Sweden reflected successful technological paths, skills and industrial networks unrelated to the deregulation wave in the 1990s. This hypothesis is supported by the central role of Ericsson in the telecom industry (cf. Nokia's position in Finland). Comparisons of ICT countries do not indicate that deregulation was a major explanation of Sweden's high productivity growth (see for example the regulated South Korean economy). The argument that deregulations were 
responsible for Sweden's high productivity growth 1995-2006 is supported by the fact that the increasing ICT share of total Swedish employment made a larger contribution to Swedish productivity growth than the productivity increases within the ICT sector itself in the 1991-2001 period (see Lind 2003, Table 3). However, it is difficult to estimate the direct relationship between deregulation and the productivity developments in, for example, Sweden (cf. Lundgren et al. 2007, 90-92). It is still an open question whether deregulation was a pivotal determinant of the Swedish productivity boom.

We shall summarize the analysis of the importance of the new economic-policy regime for Sweden's macroeconomic performance in the 1998-2007 period. Macroeconomic stability in Sweden resulted from the absence of strong symmetric demand and supply shocks in the OECD area. Sweden's relatively high GDP growth is mainly explained by the country's low GDP growth in the early 1990s and her favourable industrial composition in a period of strong recoveries abroad, especially in the East-Asian countries. It is thus not the result of a superior new economic-policy regime. Sweden's relatively low inflation (and high unemployment) 1998-2007 was largely a result of the Central Bank inflation target, but also of overambitious anti-inflationary policy, as well as of ICT technological shocks that are difficult to measure. The remarkable productivity boost in the Swedish business sector is almost exclusively related to the tele-product sector. It is an open question whether deregulation was important for the Swedish productivity boom. It is not unlikely that the high productivity growth in Sweden from the mid-1990s to the mid-2000s was a function of fundamental technological and 
organizational factors (as indicated by the notion of path dependence), not of the deregulations in the 1990s.

\section{SWEDEN DURING THE FINANCIAL CRISIS}

In the 2008-2011 period the new economic-policy regime in Sweden was seriously tested, first by a supply shock and then by a global financial crisis. The food and oil price shock in 2008 marked the end of a period with "divine coincidence" in Swedish monetary policy, a period without any serious conflict between the inflation target and the supplementary goal of stabilizing the real economy. To cool down overheating, the Central Bank in 2006 began to increase its repo rate (prime interest rate). In 2008, the Central Bank also decided to increase the repo rate by reference to international supply shocks. The bank even raised the repo rate five days before the fall of the Lehman Brothers in September 2008. This decision was later seen as a mistake by those members of the Executive Board who supported the decision. The global financial crisis was already on its way.

The U.S. subprime mortgage crisis had no immediate negative effect on Sweden's macroeconomic development. The Swedish banks ("the big four") were not holders of the poisonous kinds of assets that had financed the U.S. housing boom. Unlike Danish banks in 2007-2008, Swedish banks were not hit by a bursting housing bubble. Neither commercial banks nor other financial institutes in Sweden suffered from serious credit 
losses during the Great Recession because of bankruptcies in the Swedish business sector (see Statistics Sweden 2010, Figure 1). The biggest threat to Swedish banks during the global financial crisis was their interests in the Baltic countries, as these were hit not just by an international recession, but also by a collapsing real-estate market and a domestically-generated recession following an exceptional boom.

The Swedish Central Bank met the Great Recession by reductions in the repo rate (from October 2008 until July 2009) and by keeping the rate low and stable for a year (until July 2010). Furthermore, moving close to the liquidity trap of zero interest rates $(0.25$ per cent), the Central Bank took extraordinary measures to increase money supply. In addition, the government offered guarantees for medium-term loans to commercial banks and other financial institutions (from August 2008 to July 2011). But since there were restrictions on bonuses in this (voluntary) guarantee program, the number of participants was low. The centre-right coalition also introduced a program designed to stabilize the Swedish financial sector. The government established a Stability Fund. By contributing to this fund, financial institutions should help support financial actors in crisis.

Sweden entered the Great Recession with large surpluses in the public budgets. This gave room to stimulate the economy by built-in stabilizers, as well as by expansionary fiscal policies. Already before the recession, the centre-right coalition had reduced income taxes by so-called job tax deductions, implying decreases in both marginal and average tax rates. These tax reductions were mainly based on the structural argument that measures that would increase work incentives were necessary. In fact, job tax deductions 
were the main component of the leading government party's (Moderata Samlingspartiet) strategy to reduce unemployment and boost labour supply. Arguing for this strategy during the Great Recession, Minister of Finance Anders Borg and other representatives for the government also referred to the need for countercyclical Keynesian measures. However, according to OECD estimates, Swedish fiscal policy became more restrictive in 2008 and 2009. The political opposition and influential economists alike criticized this cautious fiscal policy and also the weak emphasis on labour market training during the Great Recession.

The centre-right coalition in the late 2000 s was not as willing as the centre-right coalition of the 1970 s and the early 1980 s to support companies in crisis. The automobile company SAAB has been threatened by bankruptcy since December 2009. The government offered loans to the automobile industry ( 5 billion SEK), credit guarantees at loans from the European Investment bank (20 billion SEK) and R\&D subsidies ( 3 billion SEK). These supports were conditional and much smaller than the corresponding grants to Swedish companies in crises after OPEC I and II.

Like other OECD countries, Sweden experienced a sharp decrease in GDP growth in the two last quarters of 2008 and in 2009. The Swedish decline in GDP growth was not exceptional in a Nordic perspective if Norway is excluded. But the fall in GDP growth 2008-2009 was larger in Sweden than in the Euro area and the OECD on average. The reason is mainly that Swedish openness was a disadvantage during the deep international recession. Given her economic specialization in products that are sensitive to the business 
cycle (raw materials and investment goods), Sweden was particularly hit by the Great Recession.

In 2008-2009, the decline in Swedish employment was not as dramatic as the fall in GDP growth. Productivity growth was therefore significantly reduced in Sweden in an international, although not in a Nordic, perspective (including 2007 data in the Norwegian case). As in other OECD countries (but not in the United States, Spain and Iceland), productivity growth was reduced during the Great Recession because of extensive labour hoarding. ${ }^{31}$ The period with low productivity growth, beginning already in the boom year 2007, put an end to the Swedish growth miracle.

Is Sweden's macroeconomic performance during the Great Recession and the following recovery evidence for the success or failure of the new economic-policy regime? The country was praised e.g. by the OECD for her strong government budget, absence of a housing bubble and of bank crisis. Swedish experts were hired by other countries to convey valuable experiences from the Swedish bank crisis in the early 1990s when the non-socialist government had provided financial support to the banks, and had also implemented nationalization and repayment programs (one bank was actually nationalized), see Gylfason et al. 2010, 21. Sweden was also admired abroad for her rapid recovery from the Great Recession. In 2010-2011, Sweden experienced high GDP growth although the GDP level is still (July 2011) below the GDP level ahead of the 2008 supply

\footnotetext{
${ }^{31}$ OECD (2011, ch. 5). By weakening the built-in-stabilizing effects on the public budget, the modest reduction in employment contributed to the small public deficits in Sweden during the financial crisis (see Swedish Fiscal Policy Council 2011, 25-45).
} 
shock and financial crisis. As in other periods of Swedish industrialism, the current recovery is export led.

It was a major advantage to Sweden to enter the economic crisis in the late 2000s with large public budget surpluses. The Swedish fiscal rules might have played a role for the large budget surplus before the crisis. But OECD countries with less restrictive fiscal guidelines including the other Nordic countries (cf. the less binding Stability and Growth Pact in the Finnish case) also displayed public budget surpluses. And the introduction of fiscal rules in Sweden was probably endogenously determined by the changes in economic-policy priorities that followed as a response to the budget crisis of the early 1990s (see the section "Living in the shadow of a deep crisis" above). Whatever the case, the Swedish government chose not to use these surpluses for an expansionary fiscal policy. Fiscal policy was in fact more expansionary in other OECD countries with a similar economic-policy regime.

As "divine coincidence" appeared again, Swedish monetary policy was an easier task in 2009-2011 than during the stagflation year 2008. The Swedish Central Bank reduced its prime rate under deflationary conditions (such as falling input prices) from October 2008 to July 2009. In 2008 and 2009, the decline in Swedish repo and internal-bank rates was similar to that of the corresponding Euro rates. The Swedish Central Bank then increased the repo rate in the late 2010 and during the first half of the 2011 to counteract a rising inflationary trend. The increase in the ECB key interest rate was more moderate and further postponed to April 2011 leading to a significant gap between the internal-bank 
rates in Sweden and the euro zone in the 2010-2011 recovery. The advantage of pursuing an independent Swedish monetary policy was obvious in the 2008-2011 period. Moreover, by extraordinary interventions in monetary markets, the Central Bank and the government helped avoid a banking crisis in Sweden. Furthermore, by showing considerable wage restraint in the 2010 negotiations, the Swedish collective bargaining system, and the wage-leading Industrial Agreement, proved highly capable of adjustment during a deep recession. What is more, the system of flexible exchange rates functioned as suggested by the macroeconomics textbook. The weakening of the SEK in late 2008 and in 2009 stimulated the Swedish economy in a recession, and the strengthening of the SEK in 2010-2011 offset the impending export-led boom. It seems also (although data are preliminary) that the recovery in GDP growth 2010-2011 was faster in Sweden than in Finland, a country with an even stronger position for export-oriented raw materials industries. Due to the EMU membership, Finland could not command help from a weakening currency in its efforts to escape the recession.

This rather idyllic picture of the new economic-policy regime (and the extraordinary policy measures) in Sweden 2008-2011 may be countered by the claim that Sweden escaped a bank crisis by luck, namely through the fast recovery of the Baltic countries. Furthermore, the strong Swedish upswing 2010-2011 largely reflected the country's export orientation and the product and regional composition of her export. Specialization in raw materials and investment goods was an advantage to Sweden when the large Western European countries recovered. Moreover, the increased weight of Asian markets in the regional composition of exports was beneficial to Sweden. The importance of the 
East-Asian countries in the upswing phase is a new phenomenon in the history of the Swedish business cycle. Thus, the explanation of Sweden's strong recovery in 2010-2011 is primarily structural.

Evaluating the performance of the new economic-policy regime in Sweden in the 20082011 period, we must also take account of the increase in unemployment (see Table $4 *$ in Appendix 2). Notwithstanding the use of ALMP measures open unemployment rose from 5.6 percent in January 2008 to 9.1 percent in January 2010, a stronger increase (in percentage points) than in the other Nordic countries (with the exception for Denmark) and in the other EU countries except for the Baltic and the Mediterranean countries excluding Italy. The unemployment performance of Sweden was worse in the late 2000s than during the second half of the 1970s and the early 1980s, two earlier periods marked by supply shocks and ensuing recession. What is more, Swedish unemployment in 20082010 was 7.6 per cent on average. Only Finland and Belgium among the small open Western European countries had equally high unemployment rates. The Swedish unemployment rate was similar to that of total OECD (see Table $1 *$ in Appendix 2).

There is support for the hypothesis that the new macroeconomic policy was successful during the Great Recession. But the success must largely be defined in terms of the objectives of the new regime itself, without any reference to the medium-term unemployment level. The new economic-policy regime in Sweden appears in a more favourable light if we compare the unemployment rate at the end of the 2000 s to that of the early 1990s (using a standardized measure). Monetary policies (together with bailouts 
in the financial sector) and flexible exchange rates contributed to a more limited increase in Swedish unemployment during the Great Recession. But the propensity for labour hoarding among Swedish firms was stronger at the end of the 2000s, and a bank crisis was avoided through the rapid recovery of the Baltic countries. ${ }^{32}$

\section{CONCLUSIONS}

A number of measures characteristic of the 1990s and 2000s, particularly the budget reforms, the deregulation of labor and product markets, the fiscal rules, the inflation targets and the central-bank independence, were introduced earlier and implemented more radically in Sweden than in other OECD countries. Sweden's sudden and resolute transition to a new economic-policy regime cannot be understood without reference to the deep early 1990s financial crisis and the following public budget crisis. At the same time, Swedish economic policy was shaped by new economic ideas, EU integration and the influential role of experts in the Ministry of Finance and the Central Bank. The power of economic professionals increased due to the budget reforms and the new legislation on central-bank independence. The professionalism of economic policy was matched by a reduction in the influence of other ministries (than the Ministry of Finance) and of labour market organizations, especially the central blue-collar federation (LO).

Sweden relied on these new economic-policy routines throughout the 1998-2007 period. In an international perspective, Sweden was no longer the country with low

\footnotetext{
${ }^{32}$ Swedish unemployment increased in the early 1990s in all sectors, for all age and ethnic groups and for both sexes. The recent economic recession primarily led to higher unemployment among young people and among blue-collar workers in manufacturing.
} 
unemployment rates (as in the 1970s and 1980s), but a country with low inflation rates. Contractionary monetary policy, not the fiscal rules or restrictive fiscal policy in general, was decisive for the relatively low Swedish inflation. At the same time, production growth was high in Sweden, a consequence of the ICT sector, and of the revival of the traditional export industries stimulated by the upswing in the East-Asian countries. The ICT sector, mainly the telecom industries, also explains the Swedish productivity (growth) miracle in Sweden between the mid-1990s and the mid-2000s. Moreover, the ICT sector contributed substantially to increasing wage gaps and also to low inflation in Sweden from the mid-1990s to the mid-2000s. Negative terms-of-trade effects due to price reductions on telecom products mitigated pressures that could have caused wage inflation in a dynamic economy. And the Central Bank failed to anticipate the huge productivity increases in the telecom industries, and thus decided on a monetary policy that was more restrictive than was required by the inflation target. Yet, it is impossible to decide whether Sweden's excellent productivity performance was caused by the deregulation wave in the 1990s or rather by technological processes, networks and capacities (especially in the telecom industries) wholly unrelated to the new economicpolicy regime.

During the Great Recession, Sweden escaped a bank crisis and similarly strong employment decline as in the early 1990s. Sweden's openness and industrial composition led to a drastic fall in GDP growth, but these economic-structural conditions also facilitated the country's recovery. An evaluation of the performance of the new economic-policy regime during the test period 2008-2011 period must take into account 
that the conduct of Swedish monetary policy was facilitated by "divine coincidence" inflation targeting turned out to be compatible with countercyclical monetary policy. Sweden benefited from her independent monetary policy, flexible exchange rates and her large public savings reducing the risk of a budget crisis and facilitating expansionary fiscal policy. But the government did not use the budget surplus to stimulate aggregate demand in 2008 and 2009. Furthermore, the fiscal rules of the new economic-policy strategy were hardly responsible for the Swedish budget surplus.

Sweden's macroeconomic success in the 1998-2011 period was less obvious in terms of employment. The unemployment rate was lower and the increase in unemployment was more moderate during the global financial crisis 2007-2011 than during the homegrown financial crises of the early 1990s (at least until the public budget crisis in Southern Europe and the United States in the summer of 2011). However, Sweden entered the recession with higher rate unemployment in the late 2000s than at the beginning of the 1990s. The more modest increase in Swedish unemployment during the Great Recession is explained not only by the expansionary monetary policy, but also by labour hoarding and luck. The new economic-policy regime in Sweden was thus helped by some favourable external conditions. In addition, the interruption of the stagflation process in 2008 made monetary policy an easier task. New increases in energy and food prices, together with a growing discontent with the deregulation of the labour and product markets, are the major challenges to the new Swedish economic-policy regime in the 2010s. 


\section{REFERENCES}

Aghion, P. et al. (2003) An Agenda for a Growing Europe - Making the EU Economic System Deliver. The "Sapir report" to the EU Commision. Brussels: EU.

Akerlof, G. A., Dickens, W.T. \& Perry, G.L. (2000). Near-rational wage and price-setting and the long-run Phillips curve. Brookings Papers on Economic Activity, (1), 1-44.

Bennmarker, H., Carling, K. and Holmlund, B. (2007). Do benefit hikes damage job finding? Evidence from Swedish unemployment insurance reforms. Labour, 21(1), 85120.

Bergström, H (1987). Rivstart? Om övergången från opposition till regering. Stockholm: Tidens Förlag.

Blanchard, O. (2011). Macroeconomics - Updated Edition, Fifth Edition. Boston: Pearson.

Blanchard, O \& Gali, J. (2007). "The macroeconomic effects of oil shocks: why are the 2000s so different from the 1970s?", NBER Working Paper Series, Working Paper 13368, National Bureau of Economic Research, Cambridge, MA.

Blyth, M. (2001). The transformation of the Swedish model: economic ideas, distributional conflict, and institutional change. World Politics, 54(1), 1-26.

Book, C. (1997). Kuppmakare och ideologiskt skifte. Om processen när socialdemokraterna upphävde valutaregleringen. Politiska institutioner och strategiskt tänkande 15. The Department of Political Science. Uppsala: Uppsala University.

Bäckström, U. (2011). Groggbordet måste bort när festen är som roligast. Dagens Nyheter, 8 May, 2011.

CESifo (2009). Main Fiscal Rules in Selected OECD Countries, 2007. Munich: Group Munich. http://www.cesifo.de.

Cotis, J.P. and Coppel, J. (2005). Business cycle dynamics in OECD countries: evidence, causes and policy implications. OECD Economics Department, Bank of Australia Economic Conference, July 11-12, 2005. Paris: OECD.

Currents Magazine (2004). Interview with Jakob Wallenberg. Currents Magazine no. 2, 2004.

Daunfeldt, S.O. \& de Luna, X. (2008). Central bank independence and price stability: evidence from OECD countries. Oxford Economic Papers, 60(3), 410-422. 
Edin Group (1995). I takt med Europa - samhällsekonomiska aspekter på lönebildningen. A report from Arbetsgivareverket, Kommunal, Kommunförbundet, Landstingsförbundet, LO, Metall, SACO, SAF, SIF and TCE. Stockholm: LO.

Edvinsson, R. (2005). Growth accumulation crisis: with new macroeconomic data for Sweden, 1800-2000. Ph.D. thesis. Stockholm Studies in Economic History 41.

Stockholm: Stockholm University.

Ekonomifakta (2011), http://www.ekonomifakta.se/sv/fakta/valfarden.

Elmbrant, B. (1993). Så föll den svenska modellen. Stockholm: Bokförlaget T. Fischer \& Co.

Erixon, L. (1997). The Golden Age of the Swedish Model-The Coherence between Capital Accumulation and Economic Policy in Sweden in the Postwar Period, Report 97:9. Oslo: Institute for Social Research (Institutt for Samfunnsforskning)

Erixon, L. (2008). The Swedish third way - as assessment of the performance and validity of the Rehn-Meidner model. Cambridge Journal of Economics, 32(3), 367-393.

Erixon, L. (2009). Misstagens psykologi. Fyra strategiska felslut i svensk ekonomisk politik". Häften för kritiska studier, (198-199), 84-102.

Erixon, L. (2010). The Rehn-Meidner model in Sweden: its rise, challenges and survival. Journal of Economic Issues, 44(3), 677-717.

Erlandsen, E. \& Lundsgaard, J. (2007). How regulatory reforms in Sweden have boosted productivity. OECD Economics Department Working Papers, no. 577. Paris: OECD.

Feldt, K.O. (1991). Alla dessa dagar... - I regeringen 1982-1990. Stockholm: Norstedts.

Fregert, K. \& Jonung, L. (2008). Inflation targeting is a success, so far: 100 years of evidence from Swedish wage contracts. The Open-Access, Open-Assessment E-Journal, 2(31). Kiel Institute for the World Economy.

Giavazzi, F. \& Mishkin, F.S. (2006). An Evaluation of Swedish Monetary Policy Between 1995 and 2005. Report from the Swedish Parliament, 2006/07:RFR1. Stockholm: The Committee on Financ.

Government Proposition 1995/96:25, En politik för arbete, trygghet och utveckling. Stockholm: Fritzes.

Gustavsson, M. (2007), The 1990s rise in Swedish earnings inequality - persistent or transitory? Applied Economics, 39(1), 25-30.

Gustavsson, M. (2008), A new picture of Swedish earnings inequality: persistent and transitory Components, 1960-1990. Review of Income and Wealth, 54(3), 324-349. 
Gylfason, T., Holmström, B., Korkman, S., Tson Söderström, H. \& Vihriälä, V. (2010). "Introduction and summary - putting the crisis into perspective", in Nordics in Global Crisies - Vulnerability and Resilience, 11-32.

http://notendur.hi.is/gylfason/nordics_in_global_crisis.pdf.

Gyll, S. et al. (1997). Nu är förtroendet förstört. A call from 101 Swedish CEOs. Dagens Nyheter, 23 February 1997.

Hayo, B. \& Hefeker, C. (2001). Do we really need central bank independence? A critical re-examination. WWZ-Discussion Paper 01/03. Basel: University of Basel.

Högselius, P. \& Kaijser, A. (2007). När folkhemselen blev internationell elavregleringen i historiskt perspektiv. Stockholm: SNS Förlag.

Holmlund, B. (2009). The Swedish unemployment experience. Oxford Review of Economic Policy, 25(1), 109-125.

Hüfner, F. (2007). Why has Swedish inflation been persistently low? OECD Economics Department Working Papers, No. 560. Paris: OECD.

Industrins Ekonomiska Råd (2011). Inför 2011 års avtalsrörelse. Stockholm: Industrins Ekonomiska Råd.

Ingves, S. \& Lind, G. (1998). Om att hantera en bankkris. Ekonomisk Debatt, 26(1), 4154.

Ingves, S. (2011). Flexibel inflationsmålspolitik i teori och praktik. Swedish Economic Association (Nationalekonomiska föreningen), Speech, 5 May 2011, Stockholm.

Jafarov, E. \& Leigh, D. (2007). Alternative fiscal rules for Norway. International Monetary Fund, WP/07/241. Washington D.C.: IMF.

Kjellberg, A. (2010). Kollektivavtalens täckningsgrad samt organisationsgraden hos arbetsgivarförbund och fackförbund. Research Reports 2010. Department of Sociology. Lund: Lund University. Updated version 2 May 2011.

Largest Companies (2011). Top 1000000 in the Nordic Countries. http://www.largestcompanies.com/default\$/cc-SE.

Lindbeck, A. (1997). The Swedish Experiment. Journal of Economic Literature, 35(3), 1273-1319.

Lindbeck, A. (2007). The Three Swedish Models. Financial Times Deutschland, 7 September 2007. 
Lindvall, J. (2004). The Politics of Purpose - Swedish Macroeconomic Policy After the Golden Age. PhD thesis Department of Political Science. Gothenburg: Gothenbutg University.

LO (2008), LO-ekonomernas manifest. Report 2008-10-06. Stockholm: LO.

Lind, D. (2003). Svensk industriproduktivitet i ett internationellt perspektiv under fyra decennier - vad kan vi lära av 1990-talet? Ekonomisk Debatt, 31(5), 39-48.

Lundgren, S. (ed.), Edquist, H. and Wallgren, A. (2007). Tillväxt i otakt. Stockholm: SNS Förlag.

Lundqvist, T. (2003). Konkurrensvisionens framväxt: konkurrenspolitik, intressen och politisk kultur. Stockholm: Institure for Future Studies (Institutet för Framtidsstudier).

Lönnroth, J. (2010). Who came first: politicians or academic economists? Gothenburg: University of Gothenburg. Prepared for the Arne Ryde seminar in Lund 1-2 October 2010.

Lundborg, P. \& Sacklén, H. (2006). Low-inflation targeting and long-run unemployment. Scandinavian Journal of Economics, 108(3), 397-418.

Masłowska, A. (2007). Discussion on the inconsistency of central bank independence measures. ACE (Åbo Centre for Economics), Discussion Paper no. 21. Turku: University of Turku.

Ministry of Finance, Revised Budget Bill of Sweden 1995 and Budget Bill of Sweden 1996. Stockholm: Ministry of Finance.

Ministry of Finance (1995). Konvergensprogram för Sverige. Stockholm: Ministry of Finance.

Ministry of Finance (1999). Updated Swedish Convergence Programme. Stockholm: Ministry of Finance.

National Institute of Economic Research (2011). Lönebildningsrapporten 2011. Summary in English: The Swedish wage Formation 2011. Stockholm: National Institute of Economic Research.

Nickell, S., Nunzita, L. \& Ochel, W. (2005). Unemployment in the OECD since the 1960s. What do we know? The Economic Journal, 115(1), 1-27.

OECD (2003). Economic Outlook. No. 74. Paris: OECD.

OECD (2005a). Employment Outlook. Paris: OECD. 
OECD (2005b). Economic Outlook. No. 78. Paris: OECD.

OECD (2007). Economic Outlook. No. 81. Special chapter: Main Fiscal Rules in Selected OECD Countries. Paris: OECD.

OECD (2008). Economic Outlook. No. 83, Paris: OECD.

OECD (2009). Employment Outlook. Paris: OECD.

OECD (2010). Employment Outlook. Paris: OECD.

OECD (2011). Economic Outlook. No. 89. OECD, Paris.

Persson, G. (1997). Den som är satt i skuld är icke fri. Min berättelse om hur Sverige återfick sunda statsfinanser. Stockholm: Atlas.

Pissarides, C. (1986). Unemployment and Vacancies in Britain. Economic Policy, 1(3), 499-559.

Pontusson, J. (2006). Whither Social Europe? Challenge, 49(6), 35-54.

Productivity Commission (1992). Forces of Productivity and Prosperity. Summary of SOU 1991:92, Produktivitetsdelegationen, 1992. Stockholm: Allmänna Förlaget.

SOU 1993:16, Nya villkor för ekonomi och politik. Ekonomikommissionens förslag. "The Lindbeck Commission”. Stockholm: Allmänna Förlaget.

SOU 1993:20. Riksbanken och prisstabiliteten (Riksbanksutredningen), Stockholm: Allmänna Förlaget.

Statistics Sweden (2006). Income Distribution Survey 2004. HE21 SM0601. Stockholm: Statistics Sweden.

Statistics Sweden (2010). Konkurser och offentliga accord 2009 (Bankruptcies and hearings on compositions without bankruptcy 2009). Statistik 2010:01. Stockholm and Östersund: Statistics Sweden and Tillväxtanalys.

Stock, J. H. \& Watson, M.W. (2002). Has the business cycle changed and why? NBER Working Paper Series, National Bureau of Economic Research, Working Paper 9127, Cambridge, MA: NBER.

Svensson, L.E.O. (2010). Förväntningar om och utvärdering av penningpolitiken: vilken roll spelar öppenhet och kommunikation? Penning- och Valutapolitik, (1), 44-80. 
Swedish National Agency for Education (2011). Statistics for upper secondary schools. Stockholm: the Swedish National Agency for Education (Skolverket). http://www.skolverket.se/statistik_och_analys.

Swedish Fiscal Policy Council (2011). Svensk Finanspolitik. Finanspolitiska rådets rapport 2011. Stockholm: Swedish Fiscal Policy Council.

Tson Söderström, H. et al. (1985). Vägen till ett stabilare Sverige. Konjunkturrådets rapport 1985. Stockholm: Industrial Council for Social and Economic Studies (SNS).

Tson Söderström, H. et al. (1992). Tillväxt utan gränser. Konjunkturrådets rapport 1992. Stockholm: Industrial Council for Social and Economic Studies (SNS).

Vartiainen, J. (2011). Nordic collective agreements - a continuous institution in a changing economic environment. In this issue.

Visser, J. (2006). Union membership statistics in 24 countries. ILR School. Ithaca: Cornell University.

Västsvenska Industri- och Handelskammaren (2008). Konsekvenser av ökat utländskt ägande i det svenska näringslivet. Report 2008:2. Gothenburg: Västsvenska Industri- och Handelskammaren.

Wehner, J. (2007). Budget reform and legislative control in Sweden. Journal of European Public Policy, 14(2), 313-332.

Westerlund, L. (2011). Nygammalt tankegods för en rationell och rättvis ekonomisk politik. Stockholm: LO.

Wibble A. (1992). Swedish Economic Association (Nationalekonomiska föreningen) (1991). Förhandlingar, Ekonomisk Debatt, 20, 76-93.

Wölfl, A., Wanner, I., Isabelle, Röhn, O. \& Nicoletti, G. (2010). Product market regulation: extending the analysis beyond OECD countries OECD Economics Department. Working Paper no. 799. Paris: OECD.

\section{OECD databases}

Corporate and Capital Income Taxes. http://www.oecd.org/ctp/taxdatabase.

Benefits and wages (e.g. net replacement rates, NRR). http://www.oecd.org/dataoecd.

Strictness of Employment Protection, http://stats.oecd.org/index.aspx.

Purschasing Power Parities for GDP and related indicators. http://stats.oecd.org/index.aspx?DataSetCode=PPPGDP. 


\section{Appendix 1: Swedish governments during the postwar period}

July 1945 - October 1951

October 1951 - October 1957

October 1957 - October 1976

October 1976 - October 1978

October 1978 - September 1979

October 1979 - May 1981

May 1981 - October 1982

October 1982 - October 1991
Social democratic majority government. Prime Minister: Per Albin Hansson (1945-46), Tage Erlander (1946-51).

Two-party coalition majority government, the Social Democratic Party and the Agrarian Party (Bondeförbundet, Centerpartiet from 1958).

Prime Minister: Tage Erlander.

Social democratic majority or minority governments. Main parliamentary support: Swedish Communist Party (Sveriges Kommunistiska Parti, Vänsterpartiet Kommunisterna from 1967). Even seats in Parliament for the non-socialist and socialist block 1973-76.

Prime Minister: Tage Erlander (1957-69), Olof Palme (1969-76).

Centre-right (non-socialist) coalition majority government, Centerpartiet (the Centre Party), Folkpartiet (the Liberal Party) and Moderata Samlingspartiet (the Conservative Party). Prime Minister: Torbjörn Fälldin (Centerpartiet).

Liberal minority government. Prime Minister: Ola Ullsten (Folkpartiet).

Centre-right (non-socialist) three-party coalition majority government, Centerpartiet, Folkpartiet and Moderata Samlingspartiet. Prime Minister: Torbjörn Fälldin.

Centre-right (non-socialist) two-party coalition minority government, Centerpartiet and Folkpartiet. Prime Minister: Torbjörn Fälldin.

Social democratic minority government. Prime Minister: Olof Palme (1982-86, Ingvar Carlsson (1986-91). Main parliamentary support: Vänsterpartiet Kommunisterna (Vänsterpartiet, the Left Party) from 1990).

Centre-right (non-socialist) four-party coalition minority government, Centerpartiet, Folkpartiet Liberalerna (Folkpartiet until 1990), 
Kristdemokratiska samhällspartiet (Christian Democratic Party) and Moderata Samlingspartiet. Prime Minister: Carl Bildt (Moderata Samlingspartiet). Main parliamentary support: Ny Demokrati (New Democracy).

October 1994 - October 2006

October 2006 -
Social Democratic minority government. Prime Minister: Ingvar Carlsson (1994-96), Göran Persson (1996-2006). Main parliamentary support: Vänsterpartiet, September 1994 - January 1995, Centerpartiet, January 1995 - Autumn 1998, Vänsterpartiet (the Left Party) and Miljöpartiet (the Green Party), Autumn 1998 - September 2006.

Centre-right (non-socialist) four-party coalition majority government 2006-2010, minority government 2010-, Centerpartiet, Folkpartiet Liberalerna, Kristdemokraterna (Kristdemokratiska samhällspartiet until 1996) and Moderata Samlingspartiet. Prime Minister: Fredrik Reinfeldt (Moderata Samlingspartiet). After the 2010 election the balance of power between the centre-right coalition and the left-green opposition rested on a new party in Parliament 2010: Sverigedemokraterna (Sweden Democrats). 


\section{Appendix 2: Macroeconomic statistics}

Table 1*: Standardized unemployment rates in OECD countries 1992-1997, 1998-2007 and 2008-2010, annual average percentage rates

\begin{tabular}{|c|c|c|c|}
\hline & 1992-97 & 1998-2007 & 2008-2010 \\
\hline Sweden & 8,7 & 6,7 & 7,6 \\
\hline Denmark & 7,4 & 4,7 & 5,6 \\
\hline Finland & 14,5 & 9,0 & 7,7 \\
\hline Norway & 5,6 & 3,5 & 3,0 \\
\hline Austria & 4,0 & 4,3 & 4,3 \\
\hline Belgium & 9,0 & 8,0 & 7,7 \\
\hline Netherlands & 5,9 & 3,9 & 3,8 \\
\hline Switzerland & 3,4 & 3,3 & 3,8 \\
\hline $\begin{array}{l}\text { Total small } \\
\text { Western European } \\
\text { countries }\end{array}$ & 7,3 & 5,4 & 5,4 \\
\hline Euro area & 10,1 & 8,8 & 9,1 \\
\hline United Kingdom & 8,8 & 5,3 & 7,0 \\
\hline United States & 6,1 & 4,9 & 8,2 \\
\hline Total OECD & 7,4 & 6,7 & 7,7 \\
\hline
\end{tabular}

Source: OECD (2005b), OECD (2011), Table 14.

Note: The rate of unemployment in Belgium 1992 was derived by data on unemployment 1992 and 1993 according to a national measure. 
Table 2*: Consumer prices indices 1992-1997, 1998-2007 and 2008-2010 (average annual percentage changes)

\begin{tabular}{|c|c|c|c|}
\hline & 1992-97 & 1998-2007 & 2008-2010 \\
\hline Sweden & 2,2 & 1,2 & 1,4 \\
\hline Denmark & 2,0 & 2,1 & 2,3 \\
\hline Finland & 1,8 & 1,5 & 2,4 \\
\hline Norway & 2,4 & 2,0 & 2,8 \\
\hline Austria & 2,3 & 1,7 & 1,8 \\
\hline Belgium & 2,0 & 1,9 & 2,3 \\
\hline Netherlands & 1,9 & 2,4 & 1,4 \\
\hline Switzerland & 1,9 & 0,8 & 0,9 \\
\hline $\begin{array}{l}\text { Total small } \\
\text { Western European } \\
\text { countries }\end{array}$ & 2,1 & 1,7 & 1,9 \\
\hline Euro area & 3,1 & 2,0 & 1,7 \\
\hline United Kingdom & 2,6 & 1,6 & 3,0 \\
\hline United States & 2,8 & 2,6 & 1,7 \\
\hline
\end{tabular}

Source: OECD (2005b) and OECD (2011), Table 18. 
Table 3*: Labour productivity growth in OECD countries, 1992-1995, 1996-2006 and 2007, 2008, 2009 and 2010, annual averages.

$\begin{array}{llllll}1992-95 & 1996-2006 & 2007 & 2008 & 2009 & 2010\end{array}$

\begin{tabular}{|c|c|c|c|c|c|c|}
\hline Sweden & 3,6 & 2,6 & 1,1 & $-1,7$ & $-3,3$ & 4,1 \\
\hline Denmark & 2,7 & 1,5 & $-1,2$ & $-2,9$ & $-2,2$ & 4,3 \\
\hline Finland & 4,0 & 2,2 & 3,0 & $-0,6$ & $-5,7$ & 3,5 \\
\hline Norway & 3,1 & 1,6 & $-1,3$ & $-2,4$ & $-1,0$ & 0,6 \\
\hline Austria & 1,8 & 1,6 & 1,8 & 0,5 & $-3,0$ & 1,2 \\
\hline Belgium & 1,7 & 1,3 & 1,2 & $-0,9$ & $-2,3$ & 1,4 \\
\hline Netherlands & 1,1 & 1,3 & 1,3 & 0,4 & $-2,8$ & 2,3 \\
\hline Switzerland & 0,8 & 1,1 & 1,0 & $-0,2$ & $-2,6$ & 2,1 \\
\hline $\begin{array}{l}\text { Total small } \\
\text { Western European } \\
\text { countries (excl. } \\
\text { Ireland) }\end{array}$ & 2,4 & 1,7 & 0,9 & $-1,0$ & $-2,9$ & 2,4 \\
\hline Ireland & 2,7 & 2,9 & 1,9 & $-2,5$ & 0,6 & 3,2 \\
\hline Euro area & 1,9 & 1,1 & 1,1 & $-0,4$ & $-2,3$ & 2,2 \\
\hline United Kingdom & 2,8 & 1,9 & 2,0 & $-0,8$ & $-3,4$ & 1,0 \\
\hline South Korea & 5,0 & 3,7 & 3,8 & 1,7 & 0,6 & 4,7 \\
\hline United States & 1,3 & 2,1 & 1,1 & 0,7 & 1,7 & 3,6 \\
\hline Total OECD & 1,7 & 1,8 & 1,5 & $-0,1$ & $-1,6$ & 2,9 \\
\hline
\end{tabular}

Source: OECD (2008) and OECD (2011), Table 12. 
Table 4*: $\quad$ Unemployment January 2010 and changes in unemployment January 2008 - January 2010 in 16 OECD countries

\begin{tabular}{|c|c|c|c|}
\hline & Jan 2010 & $\%$ change & Percentage point change \\
\hline Sweden & 9,1 & 62.5 & 3.5 \\
\hline Denmark $^{1)}$ & 7.3 & 135.5 & 4.2 \\
\hline Finland & 9.0 & 40.6 & 2.6 \\
\hline Netherlands & 4.2 & 44.8 & 1.3 \\
\hline Belgium & 8.0 & 14.2 & 1.0 \\
\hline Germany & 7.5 & -1.3 & -0.1 \\
\hline France & 10.1 & 29.5 & 2.3 \\
\hline $\mathrm{UK}^{2)}$ & 7.8 & 52.9 & 2.7 \\
\hline Austria & 5.3 & 26.2 & 1.1 \\
\hline Italy $^{3)}$ & 8.6 & 43.3 & 2.6 \\
\hline Spain & 18.8 & 113.6 & 10.0 \\
\hline Ireland & 13.8 & 193.6 & 9.1 \\
\hline Estonia $^{4)}$ & 15.5 & 166.1 & 9.3 \\
\hline Latvia & 22.9 & 346.0 & 17.3 \\
\hline Lithunia $^{5)}$ & 14.6 & 224.4 & 10.1 \\
\hline USA & 9.7 & 98.0 & 4.8 \\
\hline
\end{tabular}

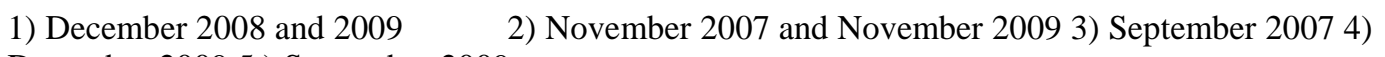

December 20095 ) September 2009

Source: Eurostat 